\title{
LEVEL II SCOUR ANALYSIS FOR BRIDGE 10 (WNDHTH00020010) on TOWN HIGHWAY 2, crossing the MIDDLE BRANCH WILLIAMS RIVER WINDHAM, VERMONT
}

U.S. Geological Survey Open-File Report 97-387

Prepared in cooperation with

VERMONT AGENCY OF TRANSPORTATION and

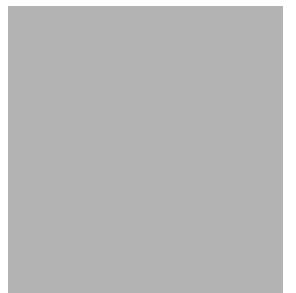




\section{LEVEL II SCOUR ANALYSIS FOR BRIDGE 10 (WNDHTH00020010) on TOWN HIGHWAY 2, crossing the MIDDLE BRANCH WILLIAMS RIVER WINDHAM, VERMONT \\ By LORA K. STRIKER and EMILY C. WILD}

U.S. Geological Survey

Open-File Report 97-387

Prepared in cooperation with

VERMONT AGENCY OF TRANSPORTATION

and

FEDERAL HIGHWAY ADMINISTRATION 


\title{
U.S. DEPARTMENT OF THE INTERIOR BRUCE BABBITT, Secretary
}

\author{
U.S. GEOLOGICAL SURVEY \\ Gordon P. Eaton, Director
}

For additional information write to:

District Chief

U.S. Geological Survey 361 Commerce Way

Pembroke, NH 03275-3718
Copies of this report may be purchased from:

U.S. Geological Survey

Branch of Information Services

Open-File Reports Unit

Box 25286

Denver, CO 80225-0286 


\section{CONTENTS}

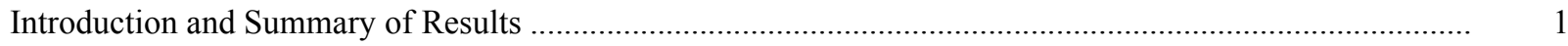

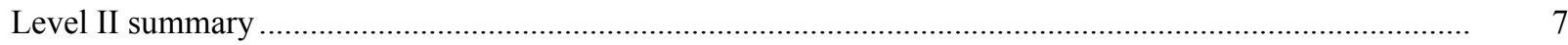

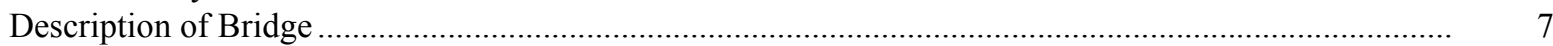

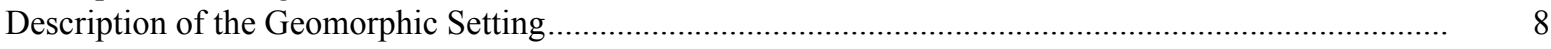

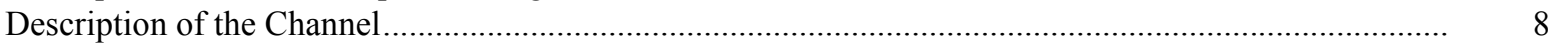

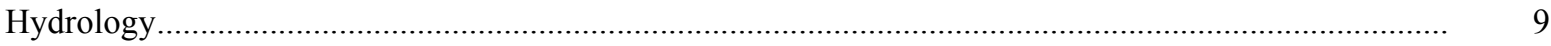

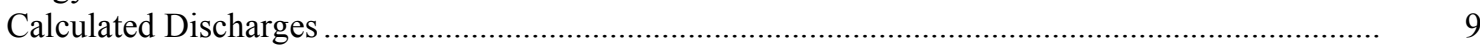

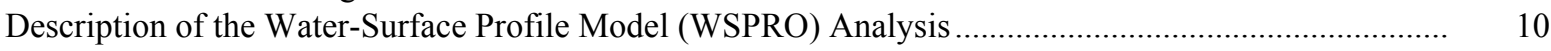

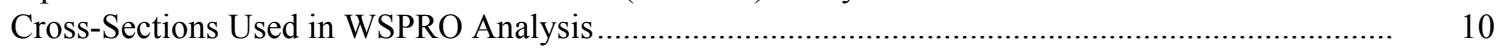

Data and Assumptions Used in WSPRO Model ...................................................................... 11

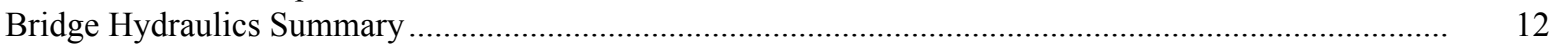

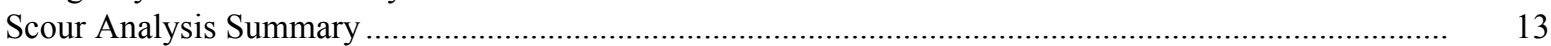

Special Conditions or Assumptions Made in Scour Analysis ...................................................... 13

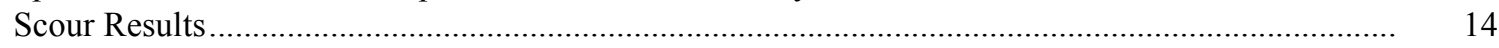

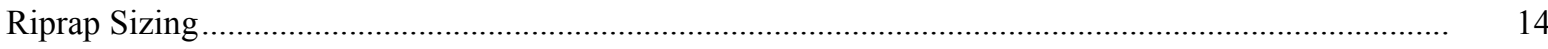

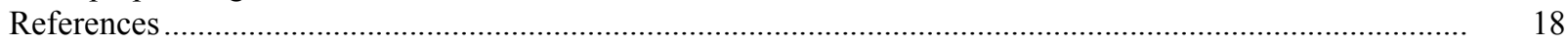

Appendixes:

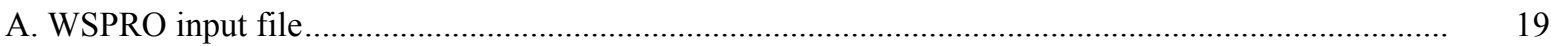

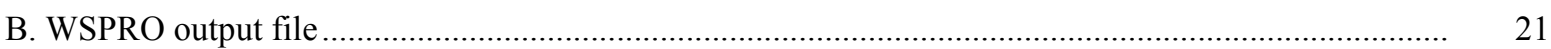

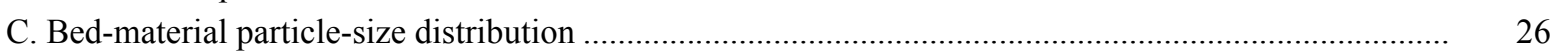

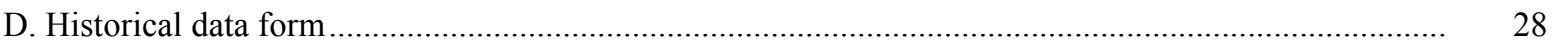

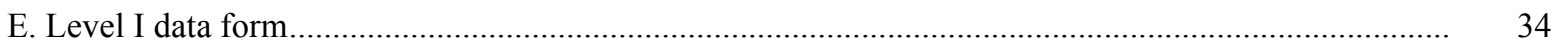

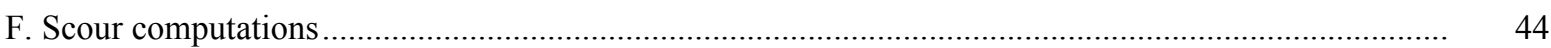

\section{FIGURES}

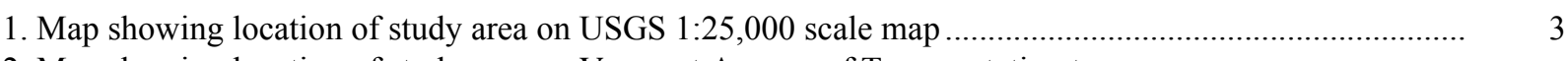

2. Map showing location of study area on Vermont Agency of Transportation town
highway map

3. Structure WNDHTH00020010 viewed from upstream (August 22, 1996) ........................................... 5

4. Downstream channel viewed from structure WNDHTH00020010 (August 22, 1996).......................... 5

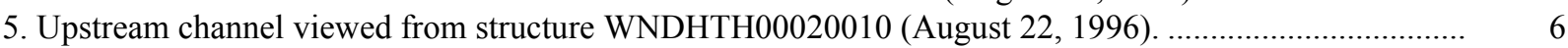

6. Structure WNDHTH00020010 viewed from downstream (August 22, 1996) ...................................... 6

7. Water-surface profiles for the 100- and 500-year discharges at structure

WNDHTH00020010 on Town Highway 2, crossing the Middle Branch Williams River, Windham, Vermont. .................................................. 15

8. Scour elevations for the 100- and 500-year discharges at structure WNDHTH00020010 on Town Highway 2, crossing the Middle Branch Williams River, Windham, Vermont.

\section{TABLES}

1. Remaining footing/pile depth at abutments for the 100-year discharge at structure WNDHTH00020010 on Town Highway 2, crossing the Middle Branch Williams River,Windham, Vermont.

2. Remaining footing/pile depth at abutments for the 500-year discharge at structure WNDHTH00020010 on Town Highway 2, crossing the Middle Branch Williams River, Windham, Vermont 


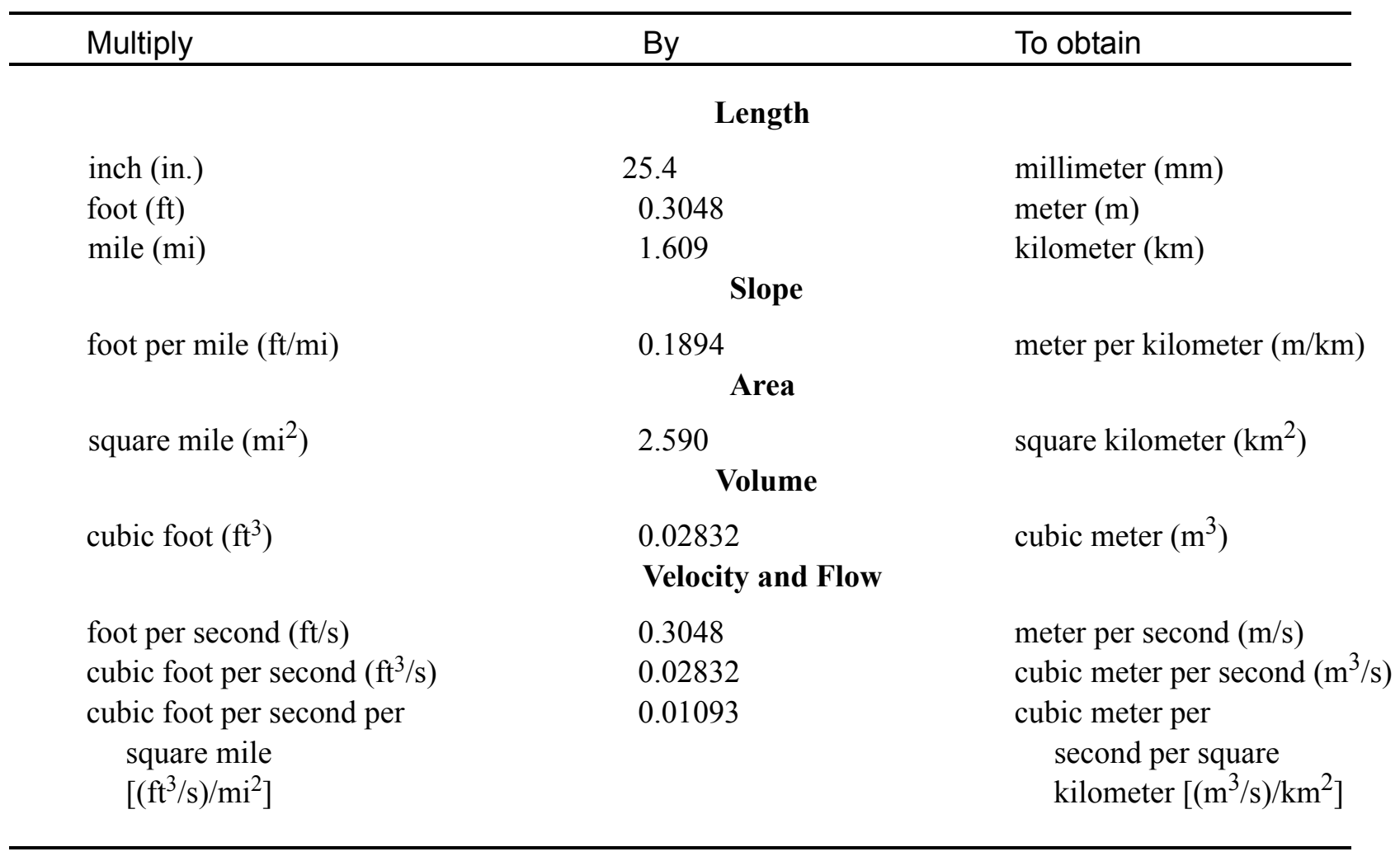

\section{OTHER ABBREVIATIONS}

$\begin{array}{lrlr}\mathrm{BF} & \text { bank full } & \text { LWW } & \text { left wingwall } \\ \mathrm{cfs} & \text { cubic feet per second } & \text { MC } & \text { main channel } \\ \mathrm{D}_{50} & \text { median diameter of bed material } & \text { RAB } & \text { right abutment } \\ \mathrm{DS} & \text { downstream } & \text { RABUT } & \text { face of right abutment } \\ \mathrm{elev} & \text { elevation } & \text { RB } & \text { right bank } \\ \mathrm{f} / \mathrm{p} & \text { flood plain } & \text { ROB } & \text { right overbank } \\ \mathrm{ft}^{2} & \text { square feet } & \text { RWW } & \text { right wingwall } \\ \mathrm{ft} / \mathrm{ft} & \text { feet per foot } & \text { TH } & \text { town highway } \\ \mathrm{JCT} & \text { junction } & \text { UB } & \text { under bridge } \\ \mathrm{LAB} & \text { left abutment } & \text { US } & \text { upstream } \\ \mathrm{LABUT} & \text { face of left abutment } & \text { USGS } & \text { United States Geological Survey } \\ \mathrm{LB} & \text { left bank } & \text { VTAOT Vermont Agency of Transportation } \\ \mathrm{LOB} & \text { left overbank } & \text { WSPRO } & \text { water-surface profile model }\end{array}$

In this report, the words "right" and "left" refer to directions that would be reported by an observer facing downstream. Sea level: In this report, "sea level" refers to the National Geodetic Vertical Datum of 1929-- a geodetic datum derived from a general adjustment of the first-order level nets of the United States and Canada, formerly called Sea Level Datum of 1929.

In the appendices, the above abbreviations may be combined. For example, USLB would represent upstream left bank. 


\title{
LEVEL II SCOUR ANALYSIS FOR BRIDGE 10 (WNDHTH00020010) ON TOWN HIGHWAY 2, CROSSING the MIDDLE BRANCH WILLIAMS RIVER, WINDHAM, VERMONT
}

\author{
By Lora K. Striker and Emily C. Wild
}

\section{INTRODUCTION AND SUMMARY OF RESULTS}

This report provides the results of a detailed Level II analysis of scour potential at structure WNDHTH00020010 on Town Highway 2 crossing the Middle Branch Williams River, Windham, Vermont (figures 1-8). A Level II study is a basic engineering analysis of the site, including a quantitative analysis of stream stability and scour (U.S. Department of Transportation, 1993). Results of a Level I scour investigation also are included in Appendix E of this report. A Level I investigation provides a qualitative geomorphic characterization of the study site. Information on the bridge, gleaned from Vermont Agency of Transportation (VTAOT) files, was compiled prior to conducting Level I and Level II analyses and is found in Appendix D.

The site is in the Green Mountain section of the New England physiographic province in south central Vermont. The $1.44-\mathrm{mi}^{2}$ drainage area is in a predominantly rural and forested basin. In the vicinity of the study site, the predominate surface cover upstream of the bridge is pasture on the left bank and forest on the right bank. Downstream of the bridge the surface cover consists of forest on the right bank and grass on the left bank.

In the study area, the Middle Branch Williams River has an incised, sinuous channel with a slope of approximately $0.03 \mathrm{ft} / \mathrm{ft}$, an average channel top width of $28 \mathrm{ft}$ and an average bank height of $5 \mathrm{ft}$. The channel bed material ranges from gravel to boulder with a median grain size $\left(\mathrm{D}_{50}\right)$ of $61.4 \mathrm{~mm}(0.201 \mathrm{ft})$. The geomorphic assessment at the time of the Level I and Level II site visit on August 22, 1996, indicated that the reach was stable.

The Town Highway 2 crossing of the Middle Branch Williams River is a 25 -ft-long, two-lane bridge consisting of one 22-foot concrete slab span (Vermont Agency of Transportation, written communication, March 31, 1995). The bridge is supported by vertical, concrete abutments with wingwalls. The channel is skewed approximately 60 degrees to the opening while the opening-skew-to-roadway is 50 degrees. 
The scour protection measures at the site included type- 2 stone fill (less than 36 inches diameter) along both upstream banks. The scour protection measures downstream were type -1 stone fill (less than 12 inches diameter) on the left bank and type-3 stone fill (less than 48 inches diameter) on the right bank. Scour protection measures do not exist underneath the bridge. Additional details describing conditions at the site are included in the Level II Summary and Appendices D and E.

Scour depths and rock rip-rap sizes were computed using the general guidelines described in Hydraulic Engineering Circular 18 (Richardson and others, 1995). Total scour at a highway crossing is comprised of three components: 1) long-term streambed degradation; 2) contraction scour (due to accelerated flow caused by a reduction in flow area at a bridge) and; 3) local scour (caused by accelerated flow around piers and abutments). Total scour is the sum of the three components. Equations are available to compute depths for contraction and local scour and a summary of the results of these computations follows.

Contraction scour for modelled flows ranged from 0.9 to $2.2 \mathrm{ft}$. The worst-case contraction scour occurred at the 500-year discharge. Abutment scour ranged from 8.5 to $8.8 \mathrm{ft}$ along the right abutment and from 8.7 to $10.1 \mathrm{ft}$ along the left abutment. The worst-case abutment scour at the right abutment occurred at the 100-year discharge and at the left abutment at the 500-year discharge. Additional information on scour depths and depths to armoring are included in the section titled "Scour Results". Scoured-streambed elevations, based on the calculated scour depths, are presented in tables 1 and 2. A cross-section of the scour computed at the bridge is presented in figure 8. Scour depths were calculated assuming an infinite depth of erosive material and a homogeneous particle-size distribution.

It is generally accepted that the Froehlich equation (abutment scour) gives "excessively conservative estimates of scour depths" (Richardson and others, 1995, p. 47). Usually, computed scour depths are evaluated in combination with other information including (but not limited to) historical performance during flood events, the geomorphic stability assessment, existing scour protection measures, and the results of the hydraulic analyses. Therefore, scour depths adopted by VTAOT may differ from the computed values documented herein. 


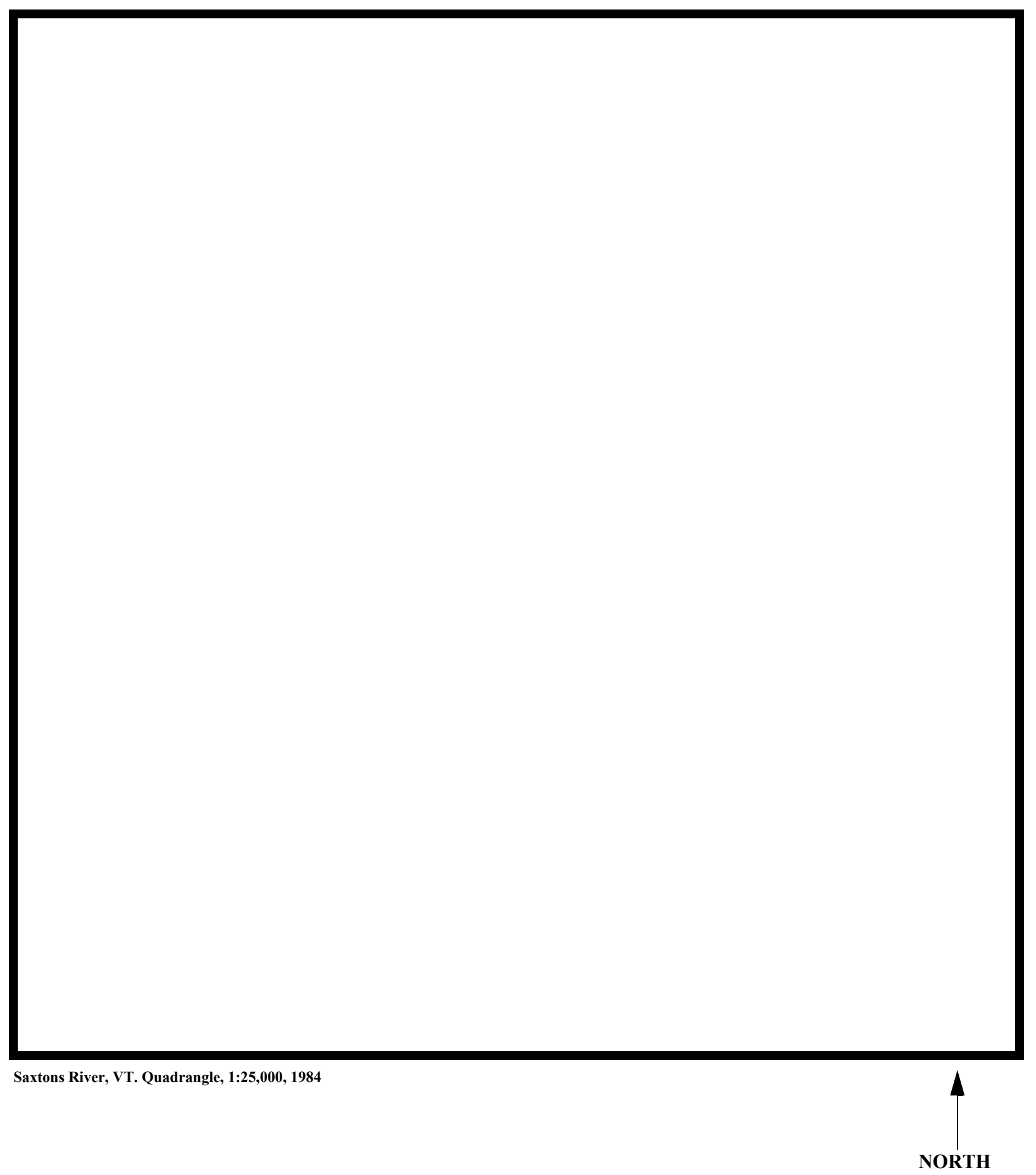

Figure 1. Location of study area on USGS 1:25,000 scale map. 
Figure 2. Location of study area on Vermont Agency of Transportation town highway map. 

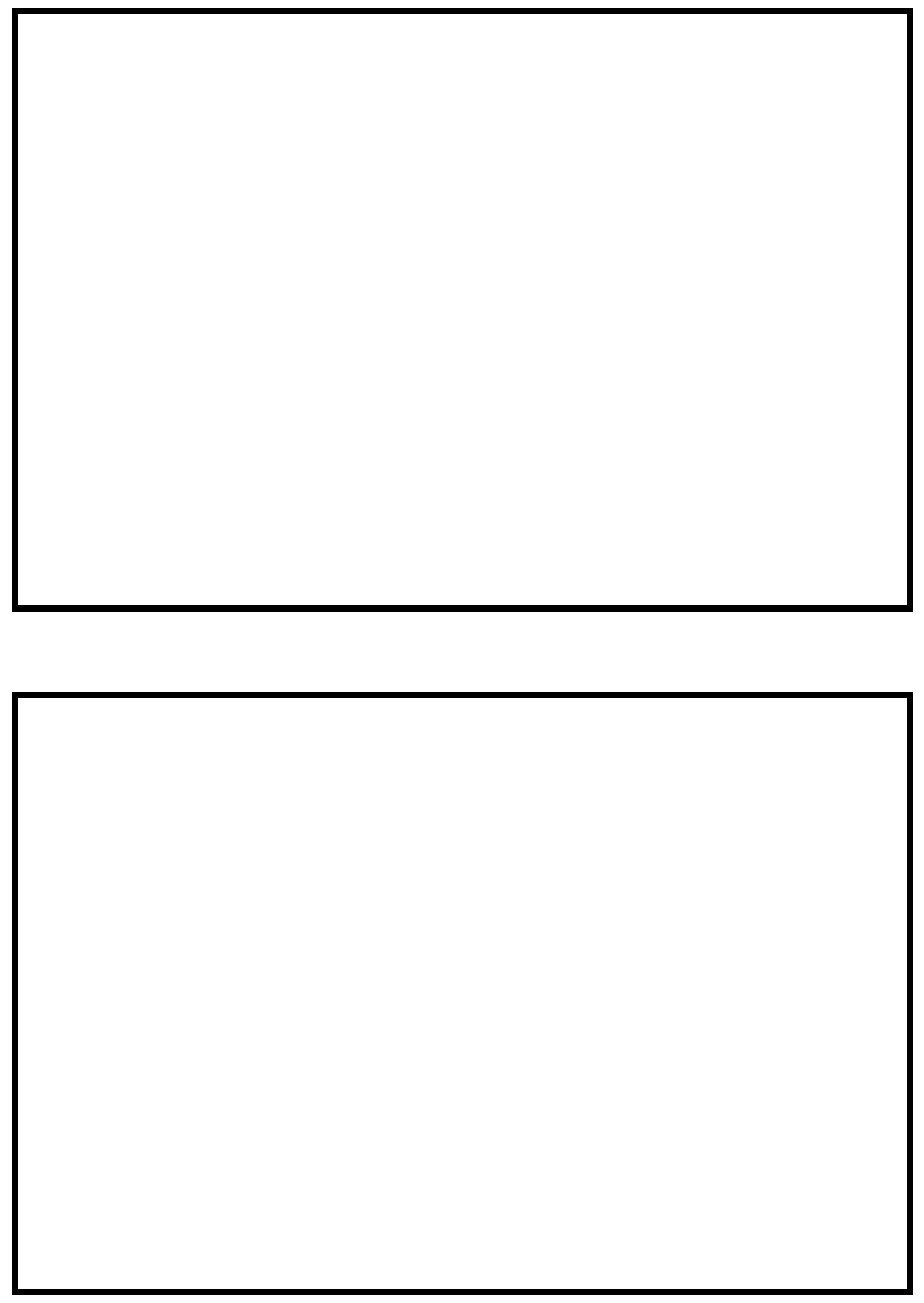

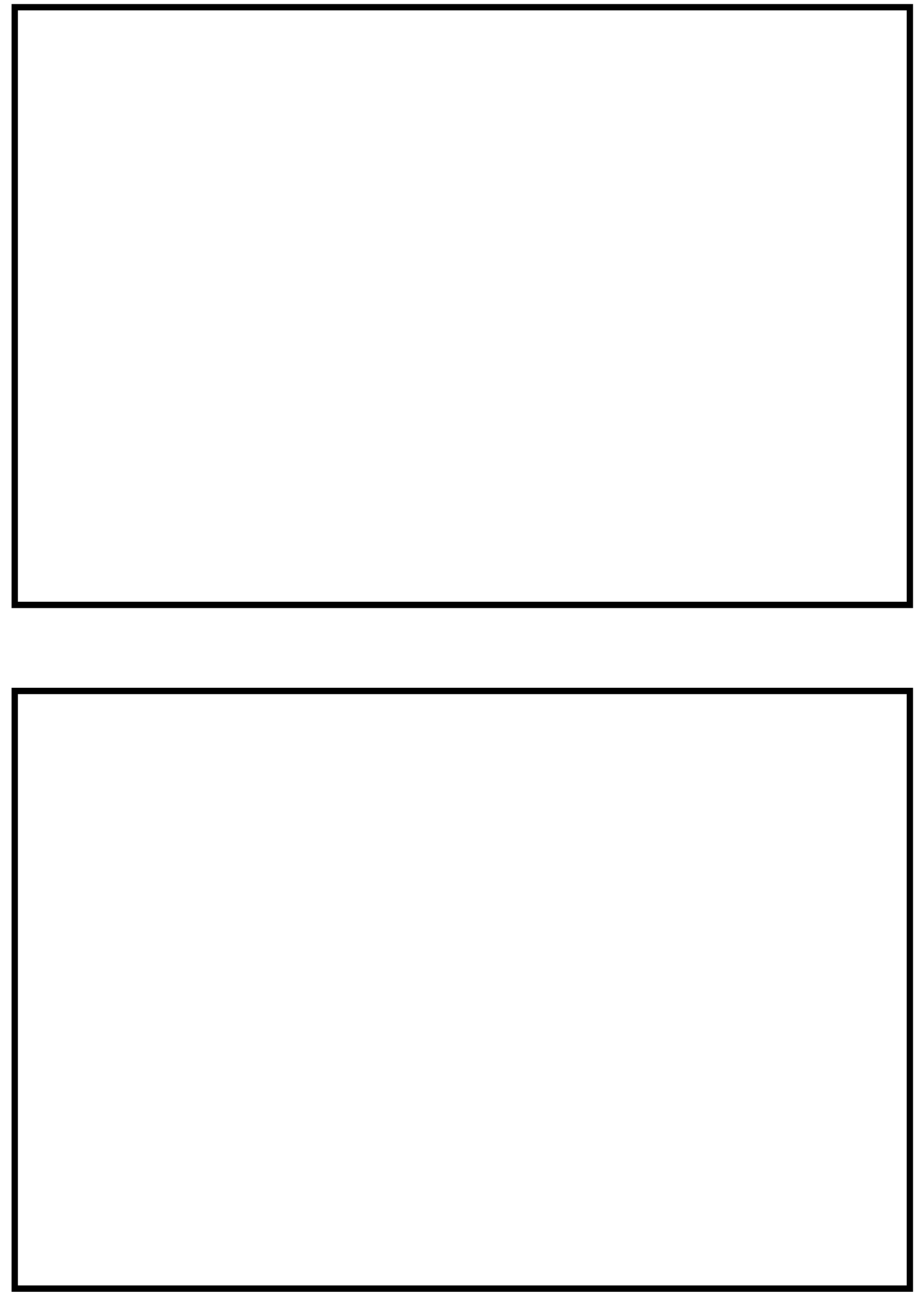


\section{LEVEL II SUMMARY}

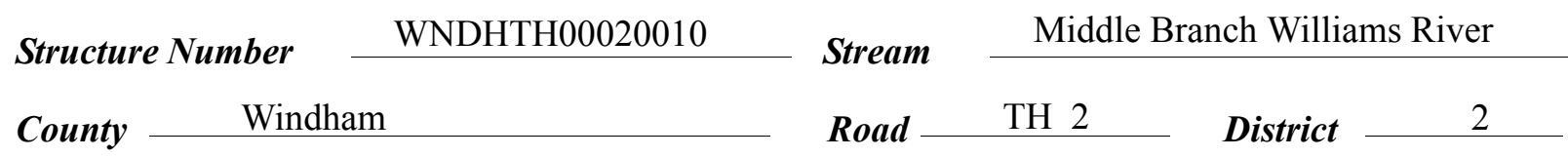

\section{Description of Bridge}

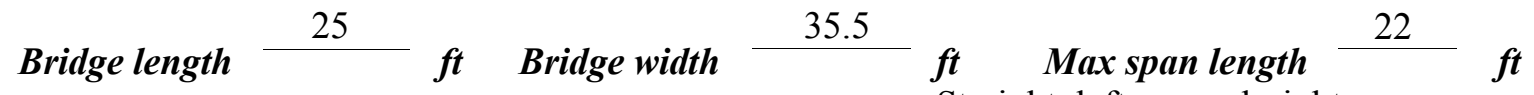
Alignment of bridge to road (on curve or straight)

Abutment type Vertical, concrete

Stone fill on abutment?

$$
\text { No }
$$

\section{Embankment type} Straight, left; curved, right

Sloping

nanamintin.. af atan a fill Type-2 along both upstream banks. Type-1 on downstream left bank and type-3 on downstream right bank.

$\ldots \quad \ldots \quad \ldots \quad \ldots \quad$ Abutments and wingwalls are concrete.

\begin{tabular}{|c|c|c|c|}
\hline & & Yes & 60 \\
\hline Is bridge skewed to flood flow according to Yes & 'survey? & & \\
\hline
\end{tabular}

Debris accumulation on bridge at time of Level I or Level II site visit:

\begin{tabular}{|c|c|c|c|}
\hline & $\begin{array}{c}\text { Date of insnortion } \\
08 / 22 / 96\end{array}$ & $\begin{array}{l}\text { Percent of rhannal } \\
\text { blocked inortzontatly }\end{array}$ & $\begin{array}{l}\text { Percent of } 0 \\
\text { blocked verticatto }\end{array}$ \\
\hline & $08 / 22 / 96$ & 0 & 0 \\
\hline
\end{tabular}

Level II The potential for debris is moderate. There is some debris caught in the vegetation along both upstream banks.

Potential for debris

Doscriho any, foaturos noar ar at tho hridoo that mav, affort flow, (includo ahsorvation dato) 


\section{Description of the Geomorphic Setting}

General topography The channel is located within a moderate relief valley with steep valley walls on both sides.

Geomorphic conditions at bridge site: downstream (DS), upstream (US)

Date of inspection $\quad 08 / 22 / 96$

DS left: $\quad$ Moderately sloped overbank to narrow flood plain

DS right: $\quad$ Narrow flood plain to steep valley wall

US left: $\quad$ Moderately sloped overbank

US right: $\quad$ Moderately sloped overbank

\section{Description of the Channel}

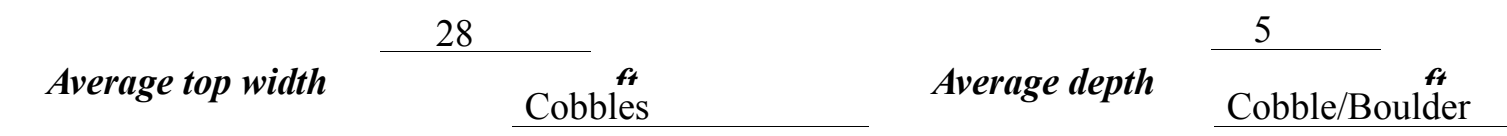

Predominant bed material

Bank material

The stream is sinuous

but stable with semi-alluvial channel boundäries and a narrow flood plain.

$08 / 22 / 96$

Vegetative co 1 Grass with trees and brush.

DS left: $\quad$ Trees and brush.

DS right: $\quad$ Trees and brush with pasture beyond tree line

US left: $\quad$ Trees and brush.

US right: $\quad$ Yes

Do banks appear stable? The banks are stable due to upstream and downstream protection.

There is evidence of slight lateral instability indicated by three cut-banks at the site. There is
date of observatton. one cut-bank along the upstream left bank from $29 \mathrm{ft}$ to $10 \mathrm{ft}$ upstream and two along the downstream right bank from $6 \mathrm{ft}$ to $23 \mathrm{ft}$ downstream and $45 \mathrm{ft}$ to

$73 \mathrm{ft}$ downstream.

The assessment of

08/22/96 noted some debris caught on both banks upstream. Describe any obstructions in channel and date of observation. 


\title{
Hydrology
}

Drainage area $\frac{1.44}{m i^{2}}$

Percentage of drainage area in physiographic provinces: (approximate)

Physiographic province/section

New England/Green Mountain
Percent of drainage area 100

\begin{abstract}
Is drainage area considered rural or urban? Rural _ Describe any significant urbanization:
\end{abstract}

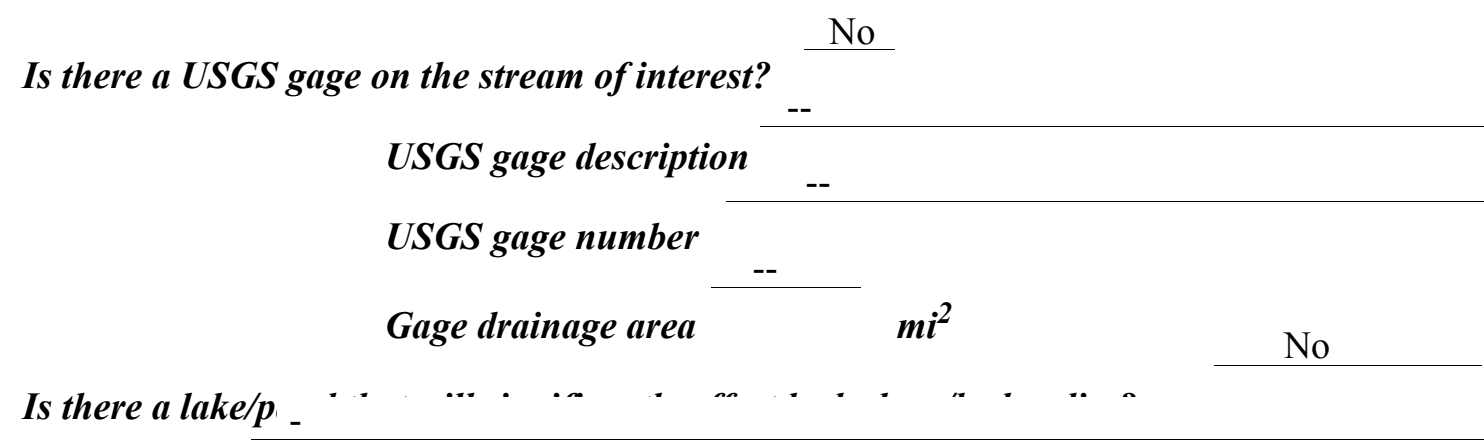

\begin{tabular}{|c|c|c|c|}
\hline 630 & & rges & 920 \\
\hline 100 & $f t^{3} / s$ & $Q 500$ & \\
\hline
\end{tabular}

The 100- and 500-year discharges are based on a

drainage area relationship.[(1.44/1.7)exp 0.67] with bridge number 23 in Windham. Bridge number 23 crosses the Middle Branch Williams River downstream of this site and has flood frequency estimates available from the VTAOT database. The drainage area above bridge number 23 is 1.7 square miles. 


\section{Description of the Water-Surface Profile Model (WSPRO) Analysis}

Datum for WSPRO analysis (USGS survey, sea level, VTAOT plans)

USGS survey

Datum tie between USGS survey and VTAOT plans

Add 1,037.26 feet to arbitrary

survey datum to obtain NGVD of 1929

Description of reference marks used to determine USGS datum. $\quad$ RM1 is a VTAOT

benchmark brass disc on top of the upstream left abutment (elev. $500.80 \mathrm{ft}$, arbitrary survey

datum). RM2 is a chiseled $\mathrm{X}$ on top of the downstream right abutment

(elev. $498.32 \mathrm{ft}$, arbitrary survey datum).

\section{Cross-Sections Used in WSPRO Analysis}

\begin{tabular}{ccll}
\hline${ }^{1}$ Cross-section & $\begin{array}{c}\text { Section } \\
\text { Reference } \\
\text { Distance } \\
\text { (SRD) in feet }\end{array}$ & $\begin{array}{c}{ }^{2} \text { Cross-section } \\
\text { development }\end{array}$ & \multicolumn{1}{c}{ Comments } \\
\hline EXITX & -25 & 1 & Exit section \\
FULLV & 0 & 2 & $\begin{array}{l}\text { Downstream Full-valley } \\
\text { section (Templated from } \\
\text { EXITX) }\end{array}$ \\
BRIDG & 0 & 1 & $\begin{array}{l}\text { Bridge section } \\
\text { Road Grade section }\end{array}$ \\
RDWAY & 28 & 1 & $\begin{array}{l}\text { Modelled Approach sec- } \\
\text { tion (Templated from } \\
\text { APTEM) }\end{array}$ \\
APTEM & 68 & 2 & $\begin{array}{l}\text { Approach section as sur- } \\
\text { veyed (Used as a tem- } \\
\text { plate) }\end{array}$ \\
\hline
\end{tabular}

${ }^{1}$ For location of cross-sections see plan-view sketch included with Level I field form, Appendix E.

For more detail on how cross-sections were developed see WSPRO input file. 


\section{Data and Assumptions Used in WSPRO Model}

Hydraulic analyses of the reach were done by use of the Federal Highway Administration's WSPRO step-backwater computer program (Shearman and others, 1986, and Shearman, 1990). The analyses reported herein reflect conditions existing at the site at the time of the study. Furthermore, in the development of the model it was necessary to assume no accumulation of debris or ice at the site. Results of the hydraulic model are presented in the Bridge Hydraulic Summary, Appendix B, and figure 7.

Channel roughness factors (Manning's “ $n$ ”) used in the hydraulic model were estimated using field inspections at each cross section following the general guidelines described by Arcement and Schneider (1989). Final adjustments to the values were made during the modelling of the reach. Channel " $\mathrm{n}$ " values for the reach ranged from 0.055 to 0.060 , and overbank " $\mathrm{n}$ " values ranged from 0.035 to 0.070 .

Normal depth at the exit section (EXITX) was assumed as the starting water surface. This depth was computed by use of the slope-conveyance method outlined in the user's manual for WSPRO (Shearman, 1990). The slope used was $0.0289 \mathrm{ft} / \mathrm{ft}$ which was estimated from surveyed thalweg points downstream of the bridge.

The surveyed approach section (APTEM) was moved along the approach channel slope $(0.0287 \mathrm{ft} / \mathrm{ft})$ to establish the modelled approach section (APPRO), one bridge length upstream

of the upstream face as recommended by Shearman and others (1986). This approach also provides a consistent method for determining scour variables. 


\section{Bridge Hydraulics Summary}

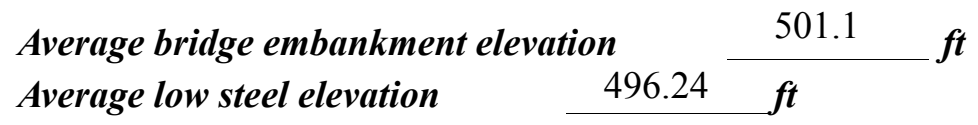

100-year discharge $\quad 630 \quad \mathrm{ft}^{3} / \mathrm{s}$

Water-surface elevation in bridge opening $\quad 496.2 \mathrm{ft}$

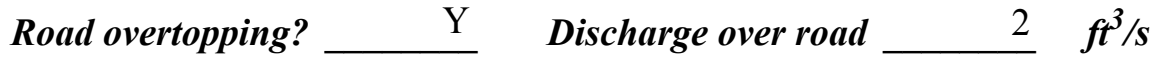

Area of flow in bridge opening $\quad 71 \quad \mathrm{ft}^{2}$

Average velocity in bridge opening $\quad 8.9 \quad \mathrm{ft} / \mathrm{s}$

Maximum WSPRO tube velocity at bridge $\quad 12.6 \mathrm{ft} / \mathrm{s}$

Water-surface elevation at Approach section with bridge 499.3

Water-surface elevation at Approach section without bridge $\quad 496.6$

Amount of backwater caused by bridge

$2.7 \quad i$

500-year discharge $\quad 920 \quad \mathrm{ft}^{3} / \mathrm{s}$

Water-surface elevation in bridge opening

$496.6 f t$

Road overtopping? ___ Y Discharge over road __ $186, \mathrm{it}^{3} / \mathrm{s}$

Area of flow in bridge opening $\quad 72 \quad \mathrm{ft}^{2}$

Average velocity in bridge opening $10.2 \mathrm{ft} / \mathrm{s}$

Maximum WSPRO tube velocity at bridge 12.4 _s

Water-surface elevation at Approach section with bridge 500.8

Water-surface elevation at Approach section without bridge $\quad 497.6$

Amount of backwater caused by bridge 3.2 .

Incipient overtopping discharge ___ _ $\quad f^{3} / \mathrm{s}$

Water-surface elevation in bridge opening $\quad-\quad t_{t}$

Area of flow in bridge opening _ _ _ $\mathrm{ft}^{2}$

Average velocity in bridge opening ___ $\quad$ _ $\mathrm{ft} / \mathrm{s}$

Maximum WSPRO tube velocity at bridge $\quad-\quad f t / s$

Water-surface elevation at Approach section with bridge

Water-surface elevation at Approach section without bridge

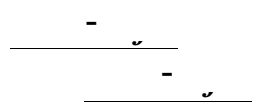

Amount of backwater caused by bridge _ _ _ t 


\section{Scour Analysis Summary}

\section{Special Conditions or Assumptions Made in Scour Analysis}

Scour depths were computed using the general guidelines described in Hydraulic Engineering Circular 18 (Richardson and others, 1995). Scour depths were calculated assuming an infinite depth of erosive material and a homogeneous particle-size distribution. The results of the scour analysis are presented in tables 1 and 2 and a graph of the scour depths is presented in figure 8 .

All modelled flows resulted in unsubmerged orifice flow with road overflow. Although there is $2 \mathrm{cfs}$ over the road, the 100-year discharge is approximately equivalent to the incipient roadway overtopping discharge. Contraction scour at bridges with orifice flow is best estimated by use of the Chang pressure-flow scour equation (oral communication, J. Sterling Jones, October 4, 1996). Thus, contraction scour for the 100-year a 500 -year discharges was computed by use of the Chang equation (Richardson and others, 1995, p. 145-146). The streambed armoring depths computed suggest that armoring will not limit the depth of contraction scour.

For comparison, contraction scour for the discharges resulting in orifice flow was also computed by use of the Laursen clear-water contraction scour equation and the Umbrell pressure-flow equation (Richardson and others, 1995, p. 144) and presented in Appendix F. Furthermore, for those discharges resulting in unsubmerged orifice flow, contraction scour was computed by substituting estimates for the depth of flow at the downstream bridge face in the contraction scour equations. Results with respect to these substitutions are provided in Appendix F.

Abutment scour was computed by use of the Froehlich equation (Richardson and others, 1995, p. 48, equation 28). Variables for the Froehlich equation include the Froude number of the flow approaching the embankments, the length of the embankment blocking flow, and the depth of flow approaching the embankment less any roadway overtopping. 


\section{Scour Results}

100-yr discharge 500-yr discharge

Incipient

Contraction scour:

(Scour depths in feet)

Main channel

Live-bed scour

Clear-water scour

Depth to armoring

Left overbank

Right overbank

Local scour:

Abutment scour

Left abutment

8.9

10.1

$8.8-$

$8.5-$

Right abutment

Pier scour

Pier 1

Pier 2

Pier 3

Abutments:

Left abutment

Right abutment

Piers:

Pier 1

Pier 2

\section{Riprap Sizing}

overtopping

discharge

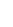




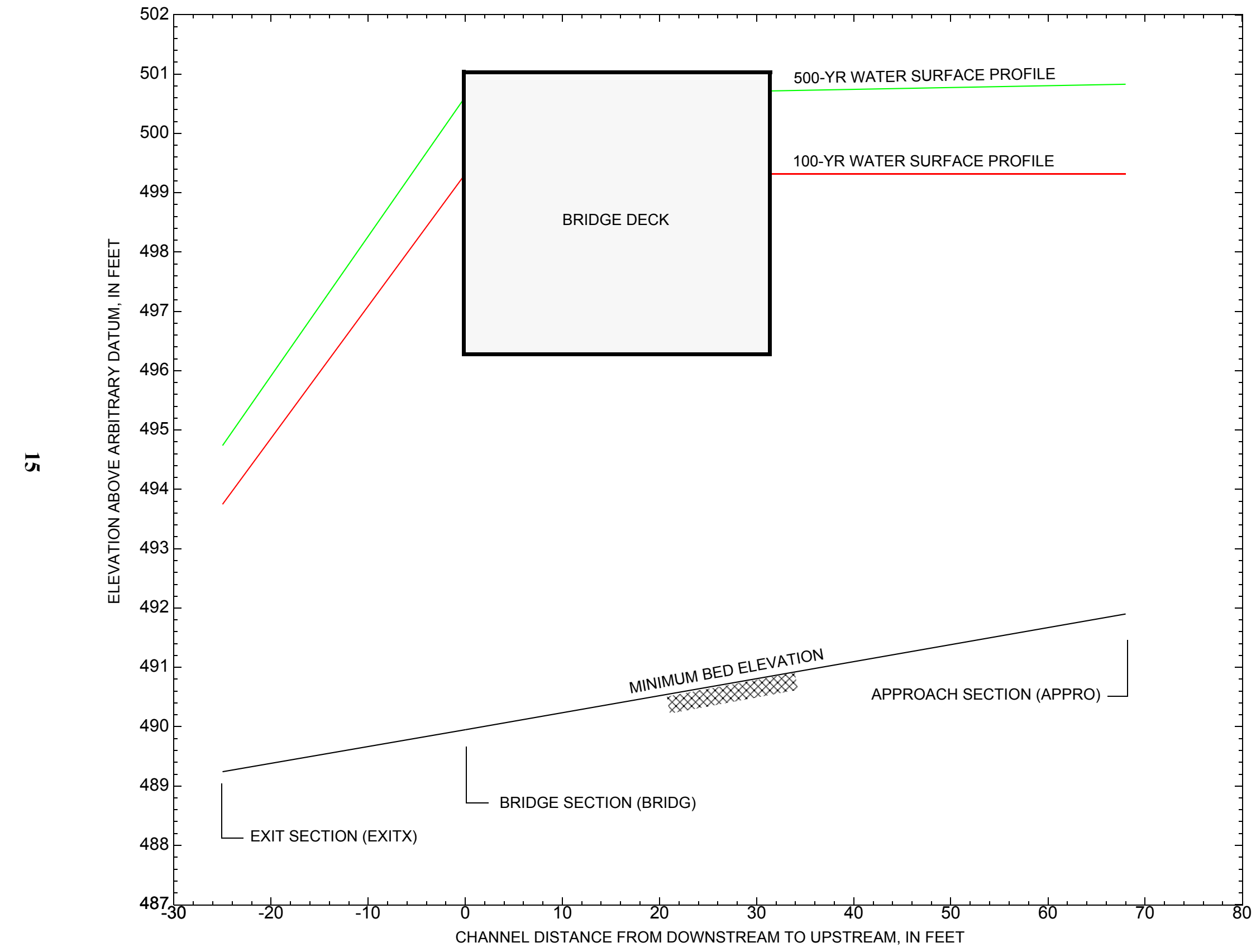

Figure 7. Water-surface profiles for the 100- and 500-yr discharges at structure WNDHTH00020010 on Town Highway 2, crossing the Middle Branch Williams River, Windham, Vermont. 


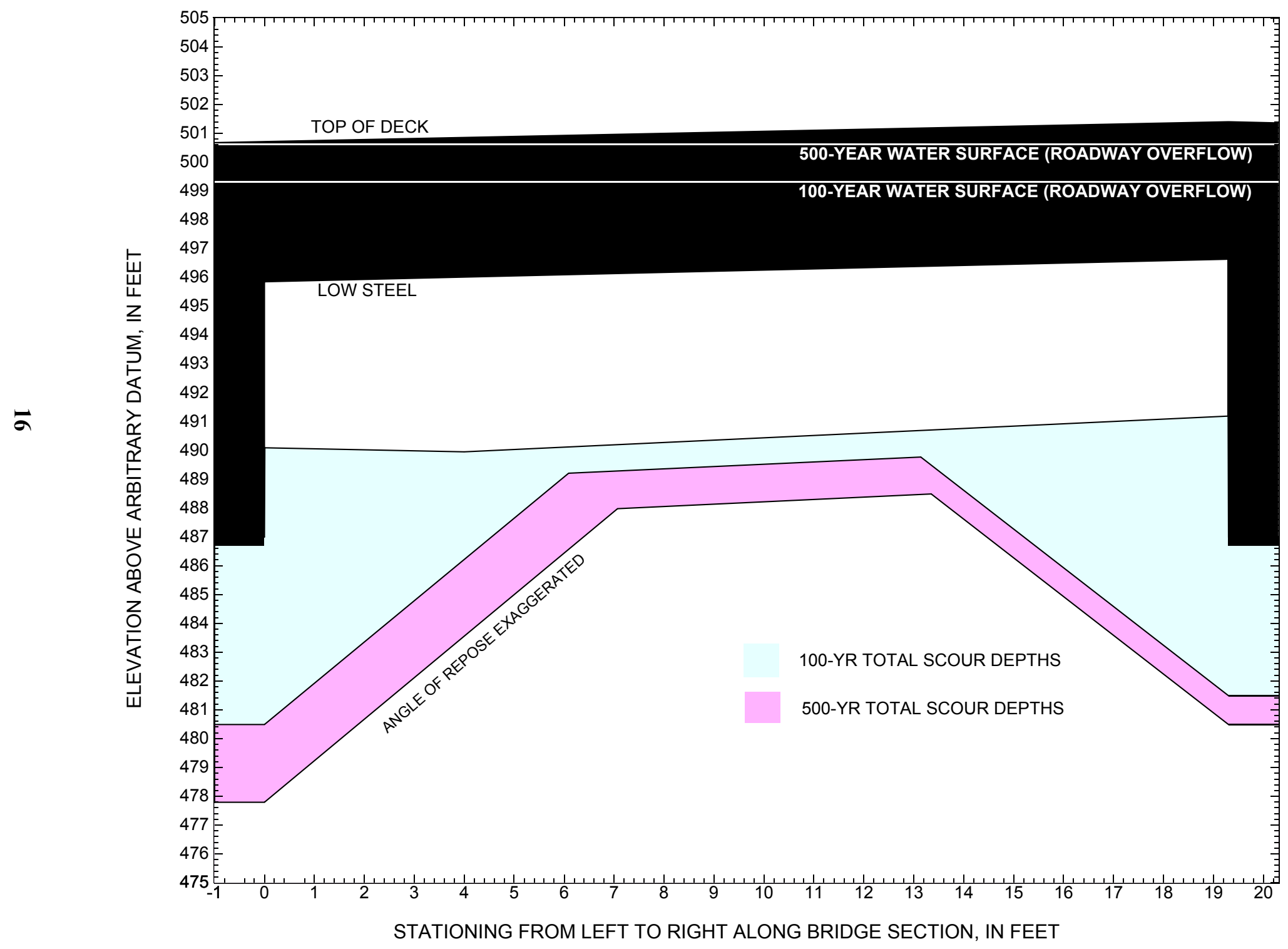

Figure 8. Scour elevations for the 100-yr and 500-yr discharges at structure WNDHTH00020010 on Town Highway 2, crossing the Middle Branch Williams River, Windham, Vermont. 
Table 1. Remaining footing/pile depth at abutments for the 100-year discharge at structure WNDHTH00020010 on Town Highway 2 , crossing the Middle Branch of the Williams River, Windham, Vermont.[VTAOT, Vermont Agency of Transportation; --,no data]

\begin{tabular}{|c|c|c|c|c|c|c|c|c|c|c|c|}
\hline Description & Station $^{1}$ & $\begin{array}{l}\text { VTAOT } \\
\text { minimum } \\
\text { low-chord } \\
\text { elevation } \\
\text { (feet) }\end{array}$ & $\begin{array}{l}\text { Surveyed } \\
\text { minimum } \\
\text { low-chord } \\
\text { elevation } \\
\text { (feet) }\end{array}$ & $\begin{array}{c}\text { Bottom of } \\
\text { footing } \\
\text { elevation } \\
\text { (feet) }\end{array}$ & $\begin{array}{c}\text { Channel } \\
\text { elevation at } \\
\text { abutment/ } \\
\text { pier }^{2} \\
\text { (feet) }\end{array}$ & $\begin{array}{l}\text { Contraction } \\
\text { scour depth } \\
\text { (feet) }\end{array}$ & $\begin{array}{l}\text { Abutment } \\
\text { scour } \\
\text { depth } \\
\text { (feet) }\end{array}$ & $\begin{array}{l}\text { Pier } \\
\text { scour } \\
\text { depth } \\
\text { (feet) }\end{array}$ & $\begin{array}{l}\text { Depth of } \\
\text { total scour } \\
\text { (feet) }\end{array}$ & $\begin{array}{c}\text { Elevation of } \\
\text { scour }^{2} \\
\text { (feet) }\end{array}$ & $\begin{array}{c}\text { Remaining } \\
\text { footing/pile } \\
\text { depth } \\
\text { (feet) }\end{array}$ \\
\hline \multicolumn{12}{|c|}{100 -yr. discharge is 630 cubic-feet per second } \\
\hline Left abutment & 0.0 & -- & 495.9 & 486.7 & 490.1 & 0.9 & 8.9 & -- & 9.8 & 480.3 & -6.4 \\
\hline Right abutment & 19.3 & -- & 496.6 & 486.7 & 491.2 & 0.9 & 8.8 & -- & 9.7 & 481.5 & -5.2 \\
\hline
\end{tabular}

1.Measured along the face of the most constricting side of the bridge.

2.Arbitrary datum for this study.

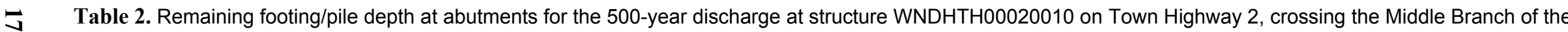
Williams River, Windham, Vermont.[VTAOT, Vermont Agency of Transportation; --, no data]

\begin{tabular}{|c|c|c|c|c|c|c|c|c|c|c|c|}
\hline Description & Station ${ }^{1}$ & $\begin{array}{l}\text { VTAOT } \\
\text { minimum } \\
\text { low-chord } \\
\text { elevation } \\
\text { (feet) }\end{array}$ & $\begin{array}{c}\text { Surveyed } \\
\text { minimum } \\
\text { low-chord } \\
\text { elevation } \\
\text { (feet) }\end{array}$ & $\begin{array}{c}\text { Bottom of } \\
\text { footing } \\
\text { elevation } \\
\text { (feet) }\end{array}$ & $\begin{array}{l}\text { Channel } \\
\text { elevation at } \\
\text { abutment/ } \\
\text { pier }^{2} \\
\text { (feet) }\end{array}$ & $\begin{array}{l}\text { Contraction } \\
\text { scour depth } \\
\text { (feet) }\end{array}$ & $\begin{array}{l}\text { Abutment } \\
\text { scour } \\
\text { depth } \\
\text { (feet) }\end{array}$ & $\begin{array}{l}\text { Pier } \\
\text { scour } \\
\text { depth } \\
\text { (feet) }\end{array}$ & $\begin{array}{l}\text { Depth of } \\
\text { total scour } \\
\text { (feet) }\end{array}$ & $\begin{array}{c}\text { Elevation of } \\
\text { scour }^{2} \\
\text { (feet) }\end{array}$ & $\begin{array}{c}\text { Remaining } \\
\text { footing/pile } \\
\text { depth } \\
\text { (feet) }\end{array}$ \\
\hline \multicolumn{12}{|c|}{ 500-yr. discharge is 920 cubic-feet per second } \\
\hline Left abutment & 0.0 & -- & 495.9 & 486.7 & 490.1 & 2.2 & 10.1 & -- & 12.3 & 477.8 & -8.9 \\
\hline Right abutment & 19.3 & -- & 496.6 & 486.7 & 491.2 & 2.2 & 8.5 & -- & 10.7 & 480.5 & -6.2 \\
\hline
\end{tabular}

1.Measured along the face of the most constricting side of the bridge.

2.Arbitrary datum for this study. 


\section{SELECTED REFERENCES}

Arcement, G.J., Jr., and Schneider, V.R., 1989, Guide for selecting Manning's roughness coefficients for natural channels and flood plains: U.S. Geological Survey Water-Supply Paper 2339, 38 p.

Barnes, H.H., Jr., 1967, Roughness characteristics of natural channels: U.S. Geological Survey Water-Supply Paper 1849,213 p.

Benson, M. A., 1962, Factors Influencing the Occurrence of Floods in a Humid Region of Diverse Terrain: U.S. Geological Survey WaterSupply Paper 1580-B, 64 p.

Brown, S.A. and Clyde, E.S., 1989, Design of riprap revetment: Federal Highway Administration Hydraulic Engineering Circular No. 11, Publication FHWA-IP-89-016, 156 p.

Federal Highway Administration, 1983, Runoff estimates for small watersheds and development of sound design: Federal Highway Administration Report FHWA-RD-77-158

Froehlich, D.C., 1989, Local scour at bridge abutments in Ports, M.A., ed., Hydraulic Engineering--Proceedings of the 1989 National Conference on Hydraulic Engineering: New York, American Society of Civil Engineers, p. 13-18.

Hayes, D.C.,1993, Site selection and collection of bridge-scour data in Delaware, Maryland, and Virginia: U.S. Geological Survey WaterResources Investigation Report 93-4017, 23 p.

Johnson, C.G. and Tasker, G.D.,1974, Progress report on flood magnitude and frequency of Vermont streams: U.S. Geological Survey OpenFile Report 74-130, 37 p.

Lagasse, P.F., Schall, J.D., Johnson, F., Richardson, E.V., Chang, F., 1995, Stream Stability at Highway Structures: Federal Highway Administration Hydraulic Engineering Circular No. 20, Publication FHWA-IP-90-014, 144 p.

Laursen, E.M., 1960, Scour at bridge crossings: Journal of the Hydraulics Division, American Society of Civil Engineers, v. 86, no. HY2, p. 39-53.

Potter, W. D., 1957a, Peak rates of runoff in the Adirondack, White Mountains, and Maine woods area, Bureau of Public Roads

Potter, W. D., 1957b, Peak rates of runoff in the New England Hill and Lowland area, Bureau of Public Roads

Richardson, E.V. and Davis, S.R., 1995, Evaluating scour at bridges: Federal Highway Administration Hydraulic Engineering Circular No. 18, Publication FHWA-IP-90-017, 204 p.

Richardson, E.V., Simons, D.B., and Julien, P.Y., 1990, Highways in the river environment: Federal Highway Administration Publication FHWA-HI-90-016.

Ritter, D.F., 1984, Process Geomorphology: W.C. Brown Co., Debuque, Iowa, 603 p.

Shearman, J.O., 1990, User's manual for WSPRO--a computer model for water surface profile computations: Federal Highway Administration Publication FHWA-IP-89-027, 187 p.

Shearman, J.O., Kirby, W.H., Schneider, V.R., and Flippo, H.N., 1986, Bridge waterways analysis model; research report: Federal Highway Administration Publication FHWA-RD-86-108, 112 p.

Talbot, A.N., 1887, The determination of water-way for bridges and culverts.

U.S. Department of Transportation, 1993, Stream stability and scour at highway bridges, Participant Workbook: Federal Highway Administration Publication FHWA HI-91-011.

U.S. Geological Survey, 1984, Saxtons River, Vermont 7.5 x 15 Minute Series quadrangle map: U.S. Geological Survey Topographic Maps, Scale 1:25,000. 


\section{APPENDIX A: \\ WSPRO INPUT FILE}




\section{APPENDIX B: \\ WSPRO OUTPUT FILE}


WSPRO OUTPUT FILE

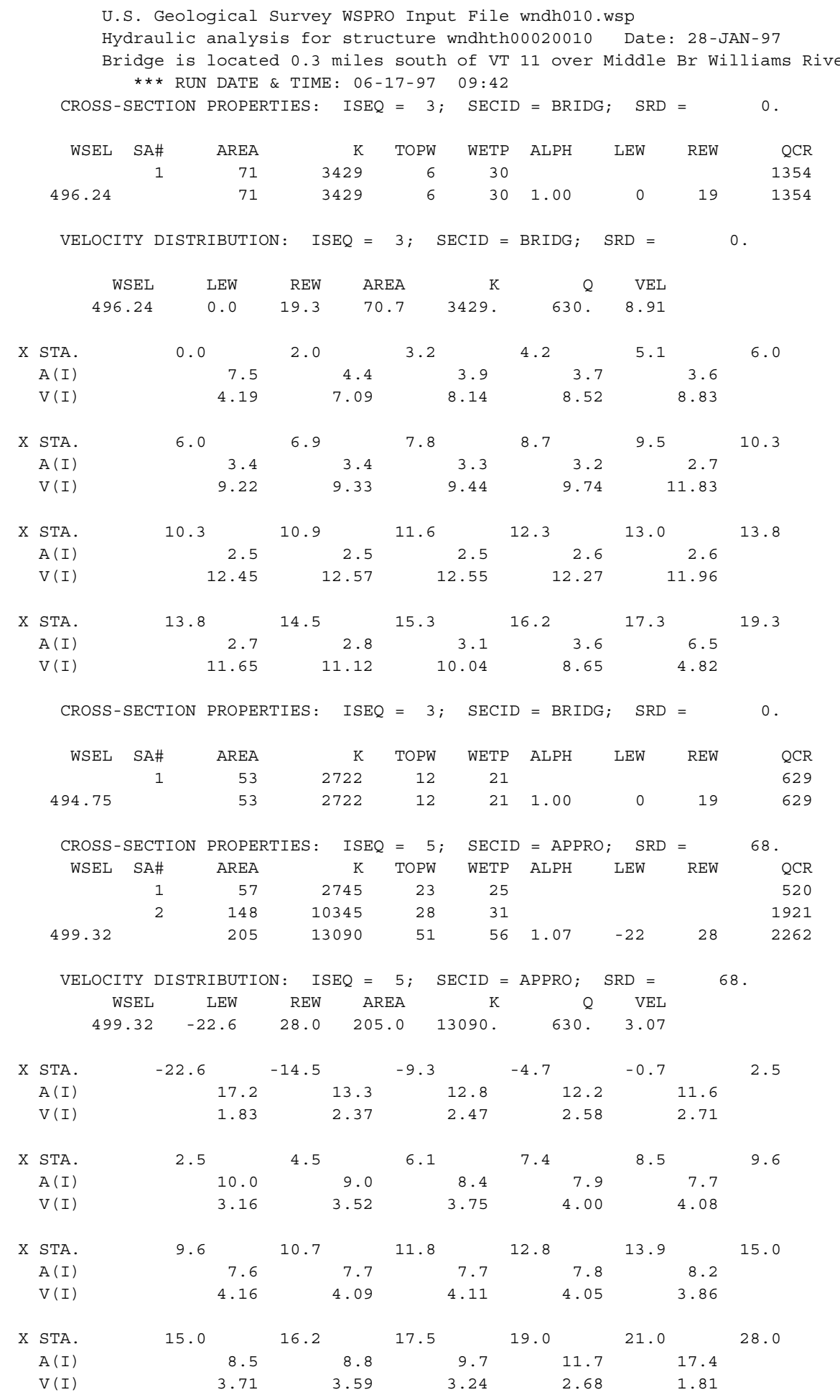




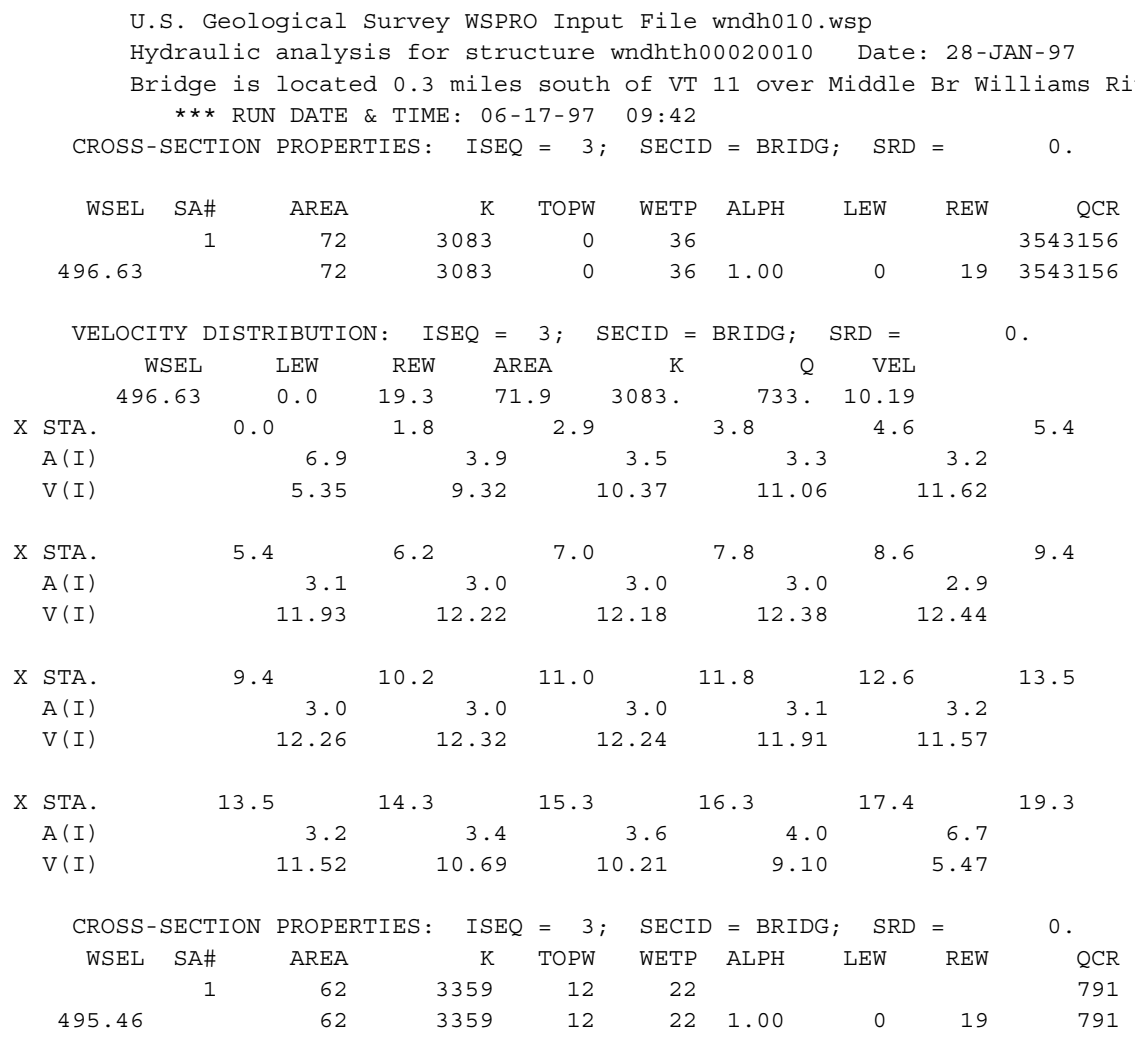

VELOCITY DISTRIBUTION: ISEQ $=4 ; \operatorname{SECID~}=$ RDWAY $\quad \operatorname{SRD}=28$.

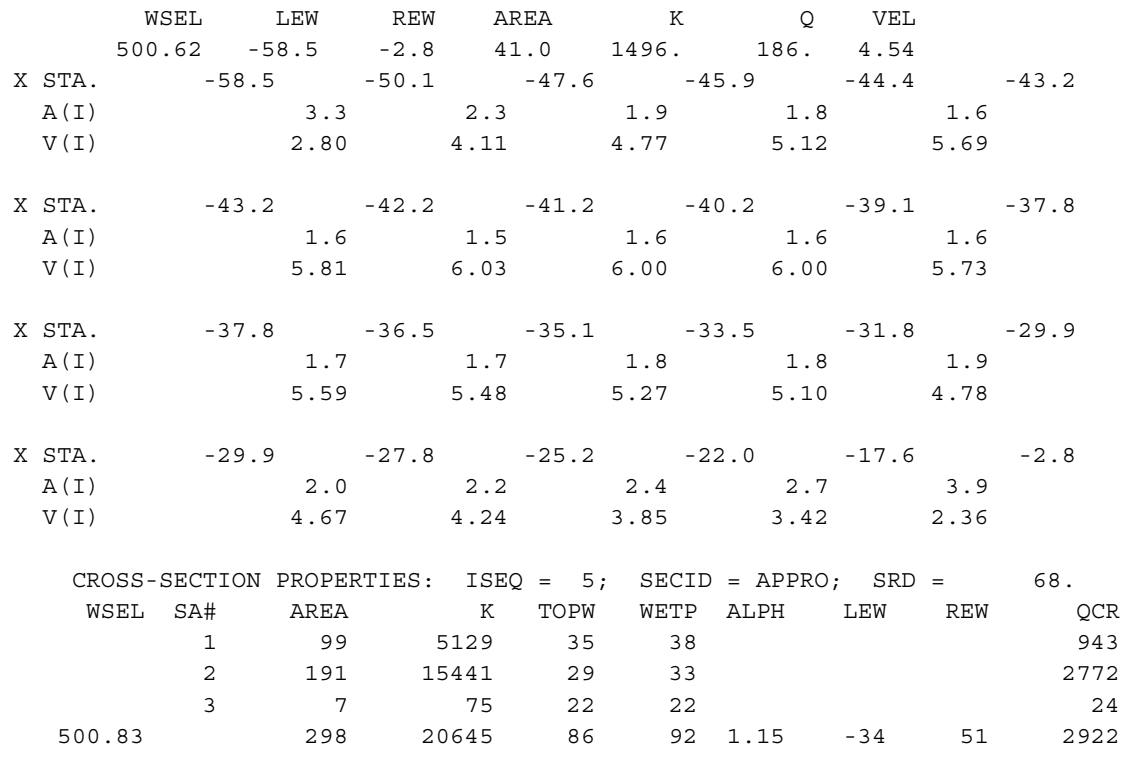

VELOCITY DISTRIBUTION: ISEQ $=5 ;$ SECID $=$ APPRO; $\quad$ SRD $=6$.

$\begin{array}{rrrrrrr}\text { WSEL } & \text { LEW } & \text { REW } & \text { AREA } & \text { K } & \text { Q } & \text { VEL } \\ 500.83 & -35.3 & 51.1 & 297.7 & 20645 . & 920 . & 3.09\end{array}$




\section{WSPRO OUTPUT FILE (continued)}

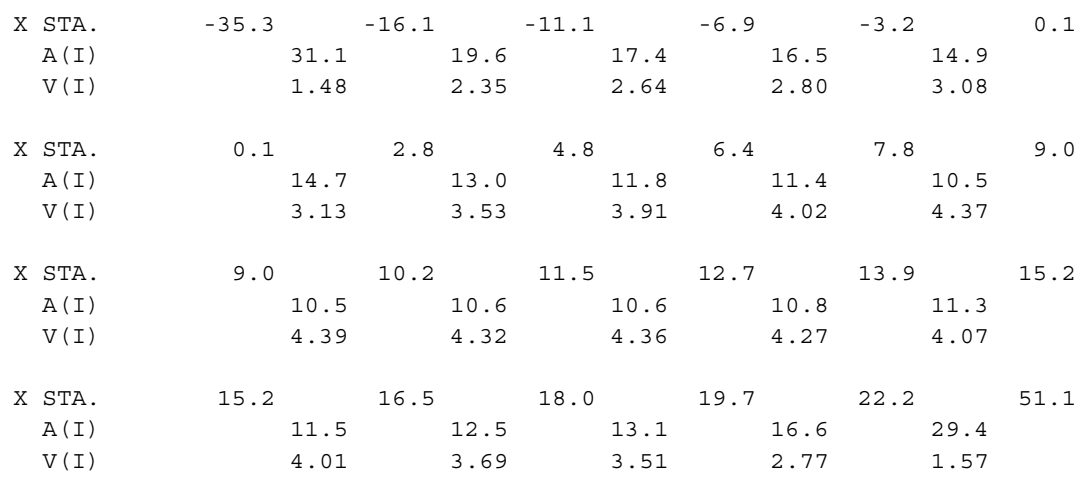

U.S. Geological Survey WSPRO Input File wndh010.wsp

Hydraulic analysis for structure wndhth00020010 Date: 28-JAN-97

Bridge is located 0.3 miles south of VT 11 over Middle Br Williams River

*** RUN DATE \& TIME: 06-17-97 09:42

$\begin{array}{rrrrrrrrrr}\text { XSID : CODE } & \text { SRDL } & \text { LEW } & \text { AREA } & \text { VHD } & \text { HF } & \text { EGL } & \text { CRWS } & \text { Q } & \text { WSEL } \\ \text { SRD } & \text { FLEN } & \text { REW } & \text { K } & \text { ALPH } & \text { HO } & \text { ERR } & \text { FR\# } & \text { VEL } & \\ \text { EXITX:XS } & * * * * * * & -2 & 73 & 1.15 & * * * * * & 494.90 & 493.34 & 630 & 493.75 \\ -24 & * * * * * * & 20 & 3706 & 1.00 * * * * * * * * * * * & 0.84 & 8.59 & \end{array}$

$==125$ FR\# EXCEEDS FNTEST AT SECID "FULLV": TRIALS CONTINUED.

$==110$ WSEL NOT FOUND AT SECID "FULLV": REDUCED DELTAY.

WSLIM1, WSLIM2, DELTAY $=493.25 \quad 501.79 \quad 0.50$

$==115$ WSEL NOT FOUND AT SECID "FULLV": USED WSMIN = CRWS

WSLIM1, WSLIM2, CRWS $=493.25 \quad 501.79 \quad 494.13$

$\begin{array}{rrrrrrrrrr}\text { FULLV : FV } & 25 & -2 & 72 & 1.18 & 0.74 & 495.67 & 494.13 & 630 & 494.49 \\ & 0 & 25 & 20 & 3620 & 1.00 & 0.02 & 0.02 & 0.86 & 8.73 \\ & <<<<<\text { THE } & \text { ABOVE } & \text { RESULTS REFLECT } & \text { "NORMAL" } & \text { (UNCONSTRICTED) } & \text { FLOW >>>> }\end{array}$

$===125$ FR\# EXCEEDS FNTEST AT SECID "APPRO": TRIALS CONTINUED.

FNTEST, FR\#, WSEL, CRWS $=\begin{array}{llll}0.80 & 0.93 & 496.57 & 496.15\end{array}$

$==110$ WSEL NOT FOUND AT SECID "APPRO": REDUCED DELTAY.

WSLIM1, WSLIM2, DELTAY $=493.99 \quad 507.83 \quad 0.50$

$==115$ WSEL NOT FOUND AT SECID "APPRO": USED WSMIN = CRWS .

WSLIM1, WSLIM2, CRWS $=493.99 \quad 507.83 \quad 496.15$

$\begin{array}{lrrrrrrrrr}\text { APPRO : AS } & 68 & -7 & 78 & 1.05 & 1.93 & 497.62 & 496.15 & 630 & 496.57\end{array}$

$<<<<$ THE ABOVE RESULTS REFLECT "NORMAL" (UNCONSTRICTED) FLOW >>>>>

$===215$ FLOW CLASS 1 SOLUTION INDICATES POSSIBLE ROAD OVERFLOW.
WS1,WSSD, WS3, RGMIN $=500.10$
$0.00 \quad 494.77$
499.02

$===260$ ATTEMPTING FLOW CLASS 4 SOLUTION.

$==240$ NO DISCHARGE BALANCE IN 15 ITERATIONS.

$$
\mathrm{WS}, \mathrm{QBO}, \mathrm{QRD}=502.01 \quad 0.630 \text {. }
$$

$===280$ REJECTED FLOW CLASS 4 SOLUTION.

$===245$ ATTEMPTING FLOW CLASS 2 (5) SOLUTION

<<<<RESULTS REFLECTING THE CONSTRICTED FLOW FOLLOW >>>>>

\begin{tabular}{|c|c|c|c|c|c|c|c|c|c|c|}
\hline XSID : CODI & \multicolumn{2}{|c|}{ SRDL } & LEW & AREA & VHD & $\mathrm{HF}$ & EGL & CRWS & $Q$ & WSEL \\
\hline SRI & \multicolumn{2}{|c|}{ FLEN } & REW & K & $\mathrm{ALPH}$ & $\mathrm{HO}$ & ERR & FR\# & VEL & \\
\hline \multirow[t]{2}{*}{ BRIDG : BR } & \multicolumn{2}{|r|}{25} & 0 & 71 & $1.23 *$ & 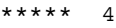 & 97.47 & 494.75 & 629 & 496.24 \\
\hline & \multicolumn{2}{|c|}{ 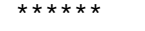 } & 19 & 3429 & 1.00 & $\star \star \star \star \star *$ & $* * * * *$ & 0.82 & 8.89 & \\
\hline TYPE & PPCD & FLOW & C & $\mathrm{P} / \mathrm{A}$ & LSEL & BLEN & XLAB & XRAB & & \\
\hline 4. & $\star \star \star \star *$ & 5. & 0.500 & 0.000 & 496.24 & 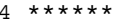 & 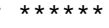 & 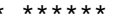 & & \\
\hline XSID: & CODE & SRD & FLEN & $\mathrm{HF}$ & VHD & EGL & ERR & Q & WSE & \\
\hline RDWAY : $\mathrm{R}$ & & 28. & 33. & 0.08 & 0.16 & 499.40 & 0.00 & 2 . & 499.3 & \\
\hline
\end{tabular}


WSPRO OUTPUT FILE (continued)

\begin{tabular}{|c|c|c|c|c|c|c|c|c|c|c|c|}
\hline & Q & WLEN & LEW & REW & DMAX & DAVG & VMAX & VAVG & HAVG & CAVG & \\
\hline LT: & 2 . & 6 . & -45 & -38. & 0.3 & 0.1 & 2.1 & 2.2 & 0.2 & 3.0 & \\
\hline RT: & 0 . & 15. & 9. & 24 . & 0.5 & 0.3 & 4.0 & 7.9 & 0.8 & 3.0 & \\
\hline XSID : CODE & SRDL & & LEW & AREA & VHD & $\mathrm{HF}$ & EGL & CRWS & & Q & WSEL \\
\hline SRD & FLEN & & REW & $\mathrm{K}$ & $\mathrm{ALPH}$ & $\mathrm{HO}$ & ERR & FR\# & & VEL & \\
\hline APPRO : AS & 13 & 3 & -22 & 205 & 0.16 & 0.15 & 499.48 & 496.15 & & 630 & 499.32 \\
\hline 68 & 17 & & 28 & 13080 & 1.07 & 0.00 & 0.00 & 0.28 & & 3.08 & \\
\hline$M(G)$ & $\mathrm{M}(\mathrm{K})$ & & $\mathrm{KQ}$ & XLKQ & XRKQ & & & & & & \\
\hline$\star \star \star * \star * *$ & 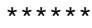 & $\star \star * * *$ & $\star \star \star \star \star \star *$ & 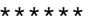 & $\star \star \star \star \star * \star *$ & $\star \star \star \star \star x$ & $* \star$ & & & & \\
\hline
\end{tabular}

FIRST USER DEFINED TABLE.

《<<<<END OF BRIDGE COMPUTATIONS $\gg \gg \gg \gg>$

\begin{tabular}{lrrrrrrrr} 
XSID $:$ CODE & \multicolumn{1}{c}{ SRD } & LEW & REW & 0 & K & AREA & VEL & WSEL \\
EXITX $:$ XS & -25. & -3. & 20. & 630. & 3706. & 73. & 8.59 & 493.75 \\
FULLV $:$ FV & 0. & -3. & 20. & 630. & 3620. & 72. & 8.73 & 494.49 \\
BRIDG $:$ BR & 0. & 0. & 19. & 629. & 3429. & 71. & 8.89 & 496.24 \\
RDWAY $:$ RG & $28 . * * * \star * *$ & 2. & 2. & 0. & 0. & 1.00 & 499.32 \\
APPRO $:$ AS & 68. & -23. & 28. & 630. & 13080. & 205. & 3.08 & 499.32
\end{tabular}

SECOND USER DEFINED TABLE.

\begin{tabular}{|c|c|c|c|c|c|c|c|c|c|}
\hline XSID : CODE & CRWS & FR\# & YMIN & YMAX & $\mathrm{HF}$ & HO & VHD & EGL & WSEL \\
\hline EXITX:XS & 493.34 & 0.84 & 489.24 & $501.00 *$ & $* * * *$ & $* * * * *$ & 1.15 & 494.90 & 493.75 \\
\hline PULL : FV & 494.13 & 0.86 & 490.03 & 501.79 & 0.74 & 0.02 & 1.18 & 495.67 & 494.49 \\
\hline BRIDG : BR & 494.75 & 0.82 & 489.95 & $496.63 *$ & $* * * * * *$ & 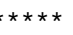 & 1.23 & 497.47 & 496.24 \\
\hline RDWAY : RG & $\star \star * \star * \star * \star * \star *$ & $\star * * * *$ & 499.02 & 508.51 & $0.08 * *$ & $* \star * \star *$ & 0.16 & 499.40 & 499.3 \\
\hline PPRO: AS & 496.15 & 0.28 & 491.90 & 507.83 & 0.15 & 0.00 & 0.16 & 499.48 & 499.3 \\
\hline
\end{tabular}

U.S. Geological Survey WSPRO Input File wndh010.wsp

Hydraulic analysis for structure wndhth00020010 Date: 28-JAN-97

Bridge is located 0.3 miles south of VT 11 over Middle Br Williams River

*** RUN DATE \& TIME: 06-17-97 09:42

\begin{tabular}{|c|c|c|c|c|c|c|c|c|c|}
\hline XSID : CODE & SRDL & LEW & AREA & VHD & $\mathrm{HF}$ & EGL & CRWS & $Q$ & WSEL \\
\hline SRD & FLEN & REW & K & $\mathrm{ALPH}$ & $\mathrm{HO}$ & ERR & FR\# & VEL & \\
\hline EXITX:XS & 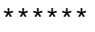 & -4 & 97 & 1.40 & $\star \star \star \star \star *$ & 496.14 & 494.28 & 920 & 494.74 \\
\hline-24 & $\star \star \star \star \star \star \star *$ & 21 & 5410 & 1.00 & $\star \star \star \star \star *$ & 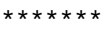 & 0.85 & 9.49 & \\
\hline
\end{tabular}

$==125$ FR\# EXCEEDS FNTEST AT SECID "FULLV": TRIALS CONTINUED.

$==110$ WSEL NOT FOUND AT SECID "FULLV":
REDUCED DELTAY

$$
\text { WSLIM1, WSLIM2, DELTAY }=494.24 \quad 501.79 \quad 0.50
$$

$===115$ WSEL NOT FOUND AT SECID "FULLV": USED WSMIN = CRWS .

WSLIM1, WSLIM2, CRWS $=494.24 \quad 501.79 \quad 495.07$

$\begin{array}{lrrrrrrrrr}\text { FULLV : FV } & 25 & -3 & 95 & 1.45 & 0.74 & 496.92 & 495.07 & 920 & 495.46 \\ & 0 & 25 & 21 & 5279 & 1.00 & 0.03 & 0.01 & 0.87 & 9.67\end{array}$

$\ll<<<$ THE ABOVE RESULTS REFLECT "NORMAL" (UNCONSTRICTED) FLOW $>>>>>$

$===125$ FR\# EXCEEDS FNTEST AT SECID "APPRO": TRIALS CONTINUED.

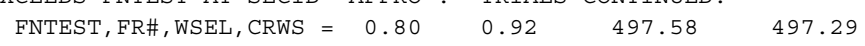

$==110$ WSEL NOT FOUND AT SECID "APPRO": REDUCED DELTAY.

$$
\text { WSLIM1, WSLIM2, DELTAY }=494.96 \quad 507.83 \quad 0.50
$$

$==115$ WSEL NOT FOUND AT SECID "APPRO": USED WSMIN = CRWS .

WSLIM1,WSLIM2, CRWS $=494.96 \quad 507.83 \quad 497.29$

$\begin{array}{llllllllll}\text { APPRO :AS } & 68 & -22 & 119 & 1.07 & 1.73 & 498.64 & 497.29 & 920 & 497.57\end{array}$

$\begin{array}{lllllllll}68 & 68 & 25 & 6309 & 1.14 & 0.00 & -0.01 & 0.93 & 7.75\end{array}$

$\ll<<<$ THE ABOVE RESULTS REFLECT "NORMAL" (UNCONSTRICTED) FLOW $>>>>>$

$===215$ FLOW CLASS 1 SOLUTION INDICATES POSSIBLE ROAD OVERFLOW.

$$
\text { WS1,WSSD ,WS3, RGMIN }=\begin{array}{lll}
502.22 & 0.00 & 495.89
\end{array}
$$

$==260$ ATTEMPTING FLOW CLASS 4 SOLUTION.

$==220$ FLOW CLASS 1 (4) SOLUTION INDICATES POSSIBLE PRESSURE FLOW.

$$
\text { WS3,WSIU,WS1, LSEL }=495.28 \quad 500.62 \quad 500.79 \quad 496.24
$$

$==245$ ATTEMPTING FLOW CLASS 2 (5) SOLUTION.

$\ll<<<$ RESULTS REFLECTING THE CONSTRICTED FLOW FOLLOW $\gg \gg>>$

XSID : CODE SRDL LEW AREA VHD HF EGL CRWS 


\section{APPENDIX C:}

\section{BED-MATERIAL PARTICLE-SIZE DISTRIBUTION}




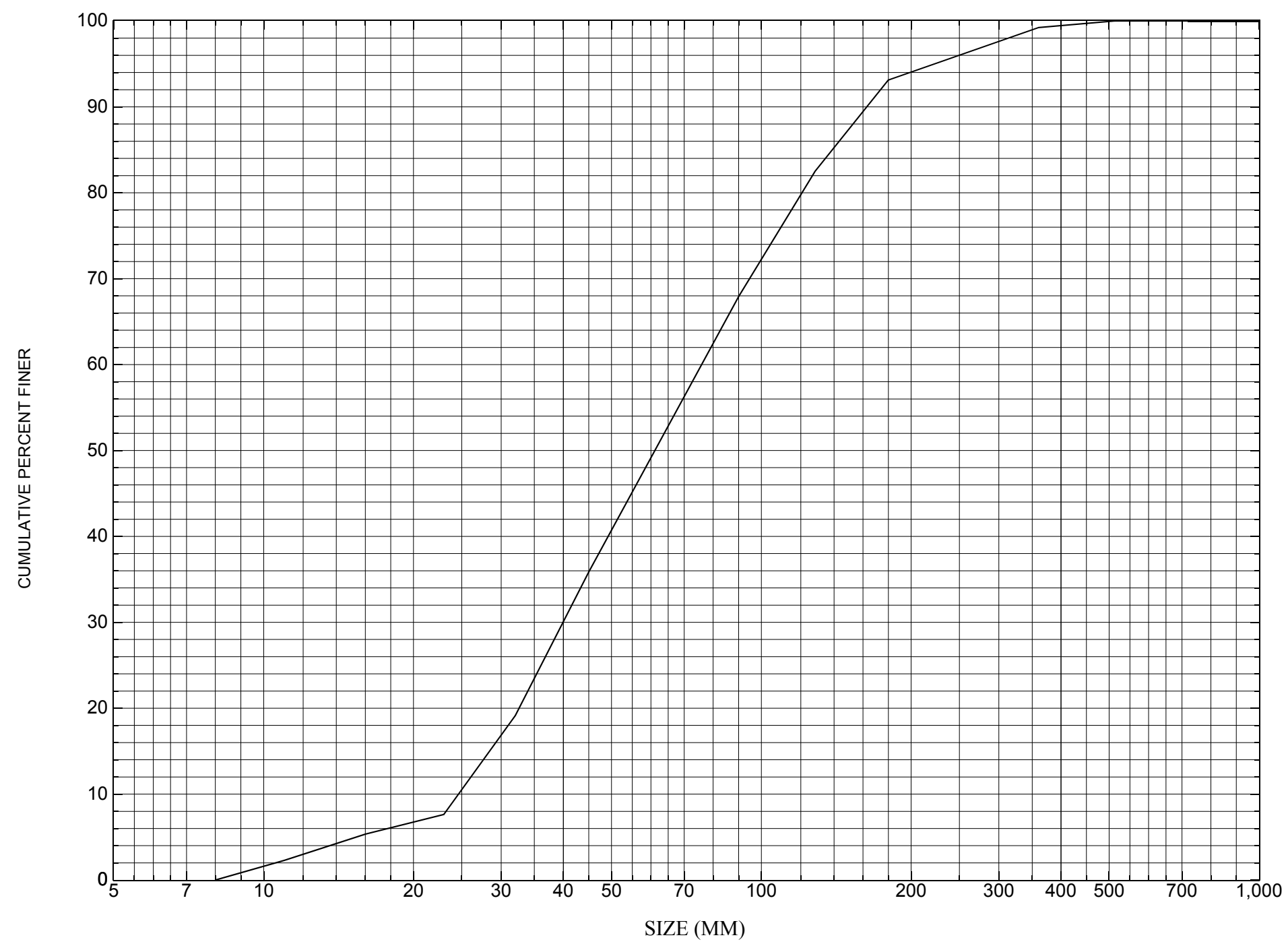

Appendix C. Bed material particle-size distribution for a pebble count in the channel approach of structure WNDHTH00020010, in Windham, Vermont. 


\section{APPENDIX D: \\ HISTORICAL DATA FORM}




\section{Structure Number WNDHTH00020010}

\section{General Location Descriptive}

Data collected by (First Initial, Full last name) $\underline{\text { L }}$. MEDALIE

Date $(M M / D D / Y Y) \_\mathbf{0 3} / \underline{31} / \underline{95}$

Highway District Number (I - 2; nn) $\mathbf{0 2}$

Town (FIPS place code; I - 4; nnnnn) $\mathbf{8 4 8 5 0}$

Waterway (I - 6) The Middle Branch Williams River

Route Number $\mathbf{\text { TH002 }}$

Topographic Map Saxtons River

Latitude (I - 16; nnnn.n) $\mathbf{4 3 1 2 8}$
County (FIPS county code; I - 3; nnn)

Mile marker (I - 11; nnn.nnn) $\mathbf{0 0 6 7 8 0}$

Road Name (I - 7): FAS 123

Vicinity (I - 9) 0.3 MI S JCT. VT.11

Hydrologic Unit Code: $\mathbf{0 1 0 8 0 1 0 7}$

Longitude (i - 17; nnnnn.n) $\mathbf{7 2 4 4 3}$

\section{Select Federal Inventory Codes}

FHWA Structure Number $(I$ - 8) $\mathbf{2 0 0 1 2 3 0 0 1 0 1 3 2 3}$

Maintenance responsibility $(I-21 ; n n)$

Year built (I - 27; YYYY) 1961

Average daily traffic, ADT (I - 29; nnnnnn) 000450

Year of ADT (I - 30; YY) $\mathbf{9 1}$

Opening skew to Roadway $(I-34 ; n n) \quad 45$

Operational status $(I-41 ; X) \quad \mathbf{A}$

Structure type (I - 43; nnn) 101

Approach span structure type $(I-44 ; n n n) \quad \mathbf{0 0 0}$

Number of spans (I - 45; nnn) $\mathbf{0 0 1}$

Number of approach spans (I - 46; nnnn) $\mathbf{0 0 0 0}$

Comments:

The structural inspection report states that the structure is a concrete slab bridge. Both concrete abutments are relatively clean. The right abutment stem has a 1/8 inch wide vertical crack extending up through the third weep hole down from the upstream end. The downstream ends of both stems have minor scaling along the flow line. All four wingwalls are in good condition. The waterway has a moderate turn through structure. The streambed consists of stone and gravel with some random boulders. The banks are well protected. There are no footings in view. There was no channel scour or embankment erosion noted in the VTAOT files.
Maximum span length (I - 48; nnnn) $\underline{\mathbf{0 0 2 2}}$

Structure length (I - 49; nnnnnn) $\underline{000025}$

Deck Width (I - 52; nn.n) $\mathbf{3 5 5}$

Channel \& Protection $(I-61 ; n) \underline{7}$

Waterway adequacy $(I-71 ; n) \underline{6}$

Underwater Inspection Frequency $(I-92 B ; X Y Y) \_$N

Year Reconstructed (I - 106) 0000

Clear span (nnn.n ft) $\mathbf{2 1 . 4 6}$

Vertical clearance from streambed (nnn.n ft) 6

Waterway of full opening $\left(n n n . n t^{2}\right)$ 


\section{Bridge Hydrologic Data}

Is there hydrologic data available? $\underline{\mathbf{N}}$ if No, type ctrl-n $h \quad$ VTAOT Drainage area $\left(m i^{2}\right)$ : -

Terrain character:

Stream character \& type: -

Streambed material: Stones and gravel

Discharge Data (cfs): $\quad \mathrm{Q}_{2.33}$

$$
\mathrm{Q}_{50}-
$$

Record flood date $(M M / D D / Y Y):-$

$\begin{array}{ll}Q_{10} \_- & Q_{25}- \\ Q_{100 \_-} & Q_{500 \_}-\end{array}$

Water surface elevation (ft): -

Estimated Discharge (cfs): Velocity at $\mathrm{Q}-$ $(\mathrm{ft} / \mathrm{s}):$

Ice conditions (Heavy, Moderate, Light) : -

Debris (Heavy, Moderate, Light):

The stage increases to maximum highwater elevation (Rapidly, Not rapidly):

The stream response is (Flashy, Not flashy):

Describe any significant site conditions upstream or downstream that may influence the stream's stage: -

Watershed storage area (in percent): - $\%$

The watershed storage area is: - (1-mainly at the headwaters; 2- uniformly distributed; 3-immediatly upstream oi the site)

Water Surface Elevation Estimates for Existing Structure:

\begin{tabular}{|l|l|l|l|l|l|}
\hline Peak discharge frequency & $Q_{2.33}$ & $Q_{10}$ & $Q_{25}$ & $Q_{50}$ & $Q_{100}$ \\
Water surface elevation (ft)) & - & - & - & - & - \\
Velocity (ft/sec) & - & - & - & - & - \\
\hline
\end{tabular}

Long term stream bed changes: -

Is the roadway overtopped below the $Q_{100}$ ? (Yes, No, Unknown):

Frequency: -

Relief Elevation $(f t)$ :

Discharge over roadway at $Q_{100}\left(f^{3} / \mathrm{sec}\right)$ :

Are there other structures nearby? (Yes, No, Unknown): If No or Unknown, type ctrl-n os Upstream distance (miles): Town: Year Built:

Highway No. : Structure No. : -

Clear span $(f t)$ : Clear Height (ft): Full Waterway $\left(f^{2}\right)$ : 
Downstream distance (miles): Town: Year Built:

Highway No. : Structure No. : Structure Type:

Clear span (ft): Clear Height $(f t)$ : Full Waterway $\left(f t^{2}\right)$ :

Comments:

\section{USGS Watershed Data}

Watershed Hydrographic Data

Drainage area (DA) 1.443

Watershed storage (ST)

Bridge site elevation 1538.4 $\mathrm{mi}^{2}$ Lake and pond area $\mathrm{mi}^{2}$ Main channel length 1.635 $\mathrm{ft}$ $\%$ $10 \%$ channel length elevation mi Headwater elevation 2893.7 $\mathrm{ft}$

Main channel slope $(S)$

1555.1 $\mathrm{ft} \quad 85 \%$ channel length elevation $\mathrm{ft}$ 577.91 $\mathrm{ft} / \mathrm{mi}$

Watershed Precipitation Data

Average site precipitation in Average headwater precipitation in

Maximum 2yr-24hr precipitation event $(124,2)$ in

Average seasonal snowfall (Sn) $\mathrm{ft}$ 


\section{Bridge Plan Data}

Are plans available? $\mathbf{N} \quad$ If no, type ctrl-n pl Date issued for construction (MM / YYYY):

Project Number

Minimum channel bed elevation:

Low superstructure elevation: USLAB DSLAB USRAB DSRAB Benchmark location description:

There is a VTAOT brass disc on top of the US left abutment (elev. 1538.058).

Reference Point (MSL, Arbitrary, Other): MSL

Datum (NAD27, NAD83, Other): NGVD 1929

Foundation Type: 1

(1-Spreadfooting; 2-Pile; 3- Gravity; 4-Unknown)

If 1: Footing Thickness $\mathbf{2 . 0} \quad$ Footing bottom elevation: $\mathbf{1 5 2 4 . 0}$

If 2: Pile Type: (1-Wood; 2-Steel or metal; 3-Concrete) Approximate pile driven length:

If 3: Footing bottom elevation:

Is boring information available? $\quad \mathbf{N}$ If no, type ctrl-n bi Number of borings taken:

Foundation Material Type: $\mathbf{3}$ (1-regolith, 2-bedrock, 3-unknown)

Briefly describe material at foundation bottom elevation or around piles:

There is no information available on the foundation material.

\section{Comments:}

The elevations were taken from a plan copy in the structural folder. 


\section{Cross-sectional Data}

Is cross-sectional data available? $\mathbf{N}$ If no, type ctrl-n xs

Source (FEMA, VTAOT, Other)? -

Comments: There is no cross section information available.

\begin{tabular}{|l|l|l|l|l|l|l|l|l|l|l|l|}
\hline Station & - & - & - & - & - & - & - & - & - & - & - \\
\hline Feature & - & - & - & - & - & - & - & - & - & - & - \\
\hline $\begin{array}{l}\text { Low cord } \\
\text { elevation }\end{array}$ & - & - & - & - & - & - & - & - & - & - & - \\
\hline $\begin{array}{l}\text { Bed } \\
\text { elevation }\end{array}$ & - & - & - & - & - & - & - & - & - & - & - \\
\hline $\begin{array}{l}\text { Low cord to } \\
\text { bed length }\end{array}$ & - & - & - & - & - & - & - & - & - & - & - \\
\hline Station & - & - & - & - & - & - & - & - & - & - & - \\
\hline Feature & - & - & - & - & - & - & - & - & - & - & - \\
\hline $\begin{array}{l}\text { Low cord } \\
\text { elevation }\end{array}$ & - & - & - & - & - & - & - & - & - & - & - \\
\hline $\begin{array}{l}\text { Bed } \\
\text { elevation }\end{array}$ & - & - & - & - & - & - & - & - & - & - & - \\
\hline $\begin{array}{l}\text { Low cord to } \\
\text { bed length }\end{array}$ & - & - & - & - & - & - & - & - & - & - & - \\
\hline
\end{tabular}

Source (FEMA, VTAOT, Other)?

Comments: There is no cross section information available.

\begin{tabular}{|l|l|l|l|l|l|l|l|l|l|l|l|}
\hline Station & - & - & - & - & - & - & - & - & - & - & - \\
\hline Feature & - & - & - & - & - & - & - & - & - & - & - \\
\hline $\begin{array}{l}\text { Low cord } \\
\text { elevation }\end{array}$ & - & - & - & - & - & - & - & - & - & - & - \\
\hline $\begin{array}{l}\text { Bed } \\
\text { elevation }\end{array}$ & - & - & - & - & - & - & - & - & - & - & - \\
\hline $\begin{array}{l}\text { Low cord to } \\
\text { bed length }\end{array}$ & - & - & - & - & - & - & - & - & - & - & - \\
\hline Station & - & - & - & - & - & - & - & - & - & - & - \\
\hline Feature & - & - & - & - & - & - & - & - & - & - & - \\
\hline $\begin{array}{l}\text { Low cord } \\
\text { elevation }\end{array}$ & - & - & - & - & - & - & - & - & - & - & - \\
\hline $\begin{array}{l}\text { Bed } \\
\text { elevation }\end{array}$ & - & - & - & - & - & - & - & - & - & - & - \\
\hline $\begin{array}{l}\text { Low cord to } \\
\text { bed length }\end{array}$ & - & - & - & - & - & - & - & - & - & - & - \\
\hline
\end{tabular}




\section{APPENDIX E: \\ LEVEL I DATA FORM}


U. S. Geological Survey

Bridge Field Data Collection and Processing Form

Qa/Qc Check by: $\underline{\mathbf{R B}}$ Date: $09 / 30 / 96$

\section{A. General Location Descriptive}

1. Data collected by (First Initial, Full last name) E. WILD

2. Highway District Number $\mathbf{0 2}$

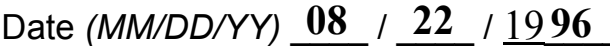

County 025 WINDHAM

Mile marker 006780

Waterway (I - 6) Middle Branch of the Williams River

Route Number TH002

Town 84850 WINDHAM

Road Name FAS 123

Hydrologic Unit Code: $\mathbf{0 1 0 8 0 1 0 7}$

3. Descriptive comments:

The bridge is located 0.3 miles south of the junction with VT 11. The structure is a concrete slab bridge. The bridge is located on the town line between Windham (on the right bank) and Londonderry (on the left bank).

\section{B. Bridge Deck Observations}
4. Surface cover... LBUS 4
RBUS 6
LBDS 4
RBDS 6
Overall 6

(2b us,ds,lb,rb: 1- Urban; 2- Suburban; 3- Row crops; 4- Pasture; 5- Shrub- and brushland; 6- Forest; 7- Wetland)
5. Ambient water surface... US $\underline{2}$
UB 2
DS $\underline{2}$
(1- pool; 2- riffle)

6. Bridge structure type 1 (1- single span; 2- multiple span; 3- single arch; 4- multiple arch; 5-cylindrical culvert; 6- box culvert; or 7- other)
7. Bridge length $\underline{\mathbf{2 5}}$
(feet)
Span length $\underline{\mathbf{2 2}}$
(feet)
Bridge width $\underline{\mathbf{3 5 . 5}}$ (feet)

\section{Road approach to bridge:}
8. LB 1
RB 2
( 0 even, 1- lower, 2- higher)
9. LB
RB 1
(1- Paved, 2- Not paved)

10. Embankment slope (run / rise in feet / foot)

US left

6.1:1

US right $\quad 2.4: 1$

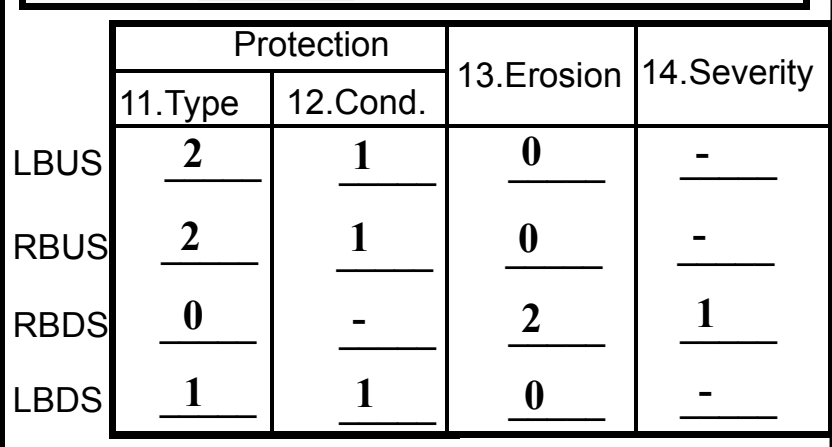

Bank protection types: 0- none; 1- $<12$ inches;

2- < 36 inches; 3- < 48 inches;

4- < 60 inches; 5- wall / artificial levee

Bank protection conditions: 1- good; 2- slumped;

3- eroded; 4- failed

Erosion: 0 - none; 1- channel erosion; 2-

road wash; 3- both; 4- other

Erosion Severity: 0 - none; 1- slight; 2- moderate; 3- severe

\section{Channel approach to bridge (BF):}

15. Angle of approach: $\mathbf{5}$

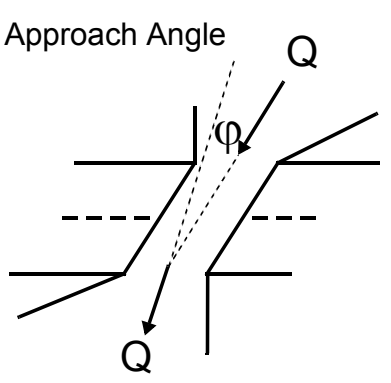

17. Channel impact zone 1 :

Where? LB $(L B, R B)$

Range? 55 feet US

Channel impact zone 2:

Where? RB (LB, RB)

Range? $\underline{4}$ feet DS

Impact Severity: 0- none to very slight; 1- Slight; 2- Moderate; 3- Severe
16. Bridge skew: $\mathbf{6 0}$ Bridge Skew Angle

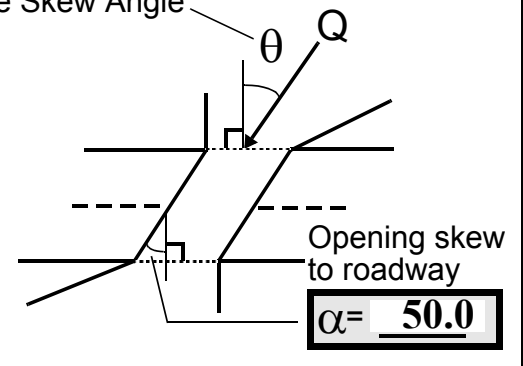

\section{Exist? $\mathbf{Y}(\mathrm{Y}$ or $N)$}

Severity 1

(US, UB, DS) to $\underline{4}$ feet $\underline{\mathbf{U S}}$

Exist? $\mathbf{Y}(Y$ or $N)$

Severity $\underline{2}$

$U B, D S)$ to $\underline{32}$ feet $\underline{\text { DS }}$ 
18. Bridge Type: 4

1a- Vertical abutments with wingwalls

$1 \mathrm{~b}$ - Vertical abutments without wingwalls

2- Vertical abutments and wingwalls, sloping embankment Wingwalls perpendicular to abut. face

3- Spill through abutments

4- Sloping embankment, vertical wingwalls and abutments

Wingwall angle less than $90^{\circ}$.

19. Bridge Deck Comments (surface cover variations, measured bridge and span lengths, bridge type variations, approach overflow width, etc.)

7. The values are from the VTAOT files. The measured bridge dimensions are the same.

4. TH 2 runs along the right bank US with a forested hill beyond. The left bank US is an open field with a few buildings on it and trees along the immediate bank. The right bank DS is forested with a small cottage on the hillside. TH 2 again runs parallel to the stream on the DS left bank for about $100 \mathrm{ft}$ at this point the stream bends.

\section{Upstream Channel Assessment}

\begin{tabular}{|c|c|c|c|c|c|c|c|c|c|c|c|}
\hline \multicolumn{5}{|c|}{ 21. Bank height (BF) 22. Bank angle (BF) } & \multicolumn{2}{|c|}{ 26. \% Veg. cover (BF) } & \multicolumn{3}{|c|}{ 27. Bank material (BF) } & \multicolumn{2}{|c|}{ 28. Bank erosion (BF } \\
\hline 20. SRD & LB & $\mathrm{RB}$ & LB & $\mathrm{RB}$ & LB & RB & LB & $\mathrm{RB}$ & & LB & $\mathrm{RB}$ \\
\hline 34.0 & 4.1 & & & 4.0 & 2 & 1 & 45 & 45 & & 1 & 1 \\
\hline 3. Bank & dth & & 24. & nel width & 35.0 & 25. Tha & weg depth & 25.5 & & Bed Material & 435 \\
\hline 30 .Bank p & otectic & pe: & LB $\underline{2}$ & RB $\underline{2}$ & & 31. Bank pr & otection cor & dition: & LB 1 & RB 1 & \\
\hline $\begin{array}{l}\text { SRD - S } \\
\text { Bed and } \\
\text { Bank Ero } \\
\text { Bank pro } \\
\text { Bank pro }\end{array}$ & on: 0 & $\begin{array}{l}\text { st. to } \\
\text { al: } 0 \\
4 \\
\text { evid } \\
\text { s: } 0 \text { - }\end{array}$ & $\begin{array}{l}\text { face } \\
\text { yanics } \\
\text { bble, } \\
1-\text { ligh } \\
\text { ent; } 1\end{array}$ & $\begin{array}{l}\% \text { Vegeta } \\
\text { t / clay, } \\
\text { 56mm; } 5 \\
\text { ial; 2- mo }\end{array}$ & $\begin{array}{l}\text { n (Veg } \\
116 \mathrm{~mm} \\
\text { oulder, } \\
\text { rate flu } \\
<36 \mathrm{in}\end{array}$ & $\begin{array}{l}\text { r: 1- } 0 \text { to } 2 \\
\text { imd, } 1 / 16 \text { - } 6-\text { bec }\end{array}$ & $\begin{array}{l}\% ; 2-26 \text { tc } \\
\text { ?mm; 3-gra } \\
\text { rock; 7- ma }\end{array}$ & $\begin{array}{l}50 \% ; 3 \\
\text { el, } 2 \text { - } \\
\text { made } \\
\text { asting }\end{array}$ & & $75 \% ; 4-76$ to & $100 \%$ \\
\hline
\end{tabular}

32. Comments (bank material variation, minor inflows, protection extent, etc.):

30. The left bank protection extends from $106 \mathrm{ft}$ US to the end of the US left wingwall. The right bank protection extends from greater than $300 \mathrm{ft}$ US to the end of the US right wingwall.

27. Bank protection on both banks consists of placed cobbles and boulders. 
36. Point bar extent: $\underline{\mathbf{3 5}}$ feet $\underline{\mathbf{U S}}$ (US, UB) to $\underline{\mathbf{3 0}}$ feet $\underline{\mathrm{UB}}$ (US, UB, DS) positioned $\underline{\mathbf{5 0}} \%$ LB to 100 \% RB

37. Material: 32

38. Point or side bar comments (Circle Point or Side; Note additional bars, material variation, status, etc.):

39. Is a cut-bank present? $\underline{\mathbf{Y}}$ ( $Y$ or if $N$ type ctrl-n cb)

40. Where? LB (LB or RB)

41. Mid-bank distance: $\mathbf{2 7}$

42. Cut bank extent: 29

43. Bank damage: 1

( 1- eroded and/or creep; 2- slip failure; 3- block failure)

44. Cut bank comments (eg. additional cut banks, protection condition, etc.):

There is less bank protection at the cut-bank along the left bank. The protection in the cut-bank area has failed from the impact.

\section{Is channel scour present? $\mathbf{N}$ ( $Y$ or if $N$ type ctrl-n cs)}

47. Scour dimensions: Length Width -

Depth : -

46. Mid-scour distance: -

48. Scour comments (eg. additional scour areas, local scouring process, etc.):

There was no channel scour present as of $08 / 22 / 96$.

\section{Are there major confluences? $\mathbf{N}$}

51. Confluence 1: Distance -

Confluence 2: Distance -

54. Confluence comments (eg. confluence name):

There are no major confluences at the site.

\section{Under Bridge Channel Assessment}

55. Channel restraint (BF)? LB 2 (1- natural bank; 2- abutment; 3- artificial levee)

\begin{tabular}{|l} 
56. Height (BF) \\
LB RB \\
$\mathbf{1 2 . 0}$ \\
58. Bank width (BF) -
\end{tabular}

\begin{tabular}{cc}
57 & Angle (BF) \\
LB & RB \\
0.5 & \\
\hline
\end{tabular}

61. Material (BF)

LB $\quad$ RB

62. Erosion (BF)

$\underline{2} \quad \underline{7}$

LB RB

7

60. Thalweg depth $(\mathrm{Amb}) \quad \mathbf{9 0 . 0}$

63. Bed Material -

Bed and bank Material: 0- organics; 1- silt / clay, < 1/16mm; 2- sand, 1/16 - 2mm; 3- gravel, 2 - 64mm; 4- cobble, 64 - 256mm; 5- boulder, > 256mm; 6- bedrock; 7- manmade

Bank Erosion: 0- not evident; 1- light fluvial; 2- moderate fluvial; 3- heavy fluvial / mass wasting

64. Comments (bank material variation, minor inflows, protection extent, etc.):

43 
65. Debris and Ice Is there debris accumulation?

$(Y$ or $N)$ 66. Where? $\underline{Y}$

(1- Upstream; 2- At bridge; 3- Both)

67. Debris Potential 1 (1-Low; 2-Moderate; 3- High)

68. Capture Efficiency 2

(1-Low; 2- Moderate; 3- High)

69. Is there evidence of ice build-up? 2

Ice Blockage Potential $\mathbf{N}$

(1- Low; 2- Moderate; 3- High)

70. Debris and Ice Comments:

1

65. There is debris caught in the vegetation along both banks.

\begin{tabular}{|l|c|c|c|c|c|c|c|c|}
\hline Abutments & $\begin{array}{c}\text { 71. Attack } \\
\angle \mathrm{BF})\end{array}$ & $\begin{array}{c}\text { 72. Slope } \\
(\mathrm{Qmax})\end{array}$ & $\begin{array}{l}\text { 73. Toe } \\
\text { loc. (BF) }\end{array}$ & $\begin{array}{c}\text { 74. Scour } \\
\text { Condition }\end{array}$ & $\begin{array}{c}\text { 75. Scour } \\
\text { depth }\end{array}$ & $\begin{array}{c}\text { 76. Exposure } \\
\text { depth }\end{array}$ & 77. Material & 78. Length \\
\hline LABUT & & $\mathbf{3 0}$ & $\mathbf{9 0}$ & $\mathbf{2}$ & $\mathbf{0}$ & - & - & $\mathbf{9 0 . 0}$ \\
\hline RABUT & $\mathbf{1}$ & $\mathbf{0}$ & $\mathbf{9 0}$ & & & $\mathbf{2}$ & $\mathbf{0}$ & $\mathbf{1 4 . 0}$ \\
\hline
\end{tabular}

Pushed: $L B$ or RB

Toe Location (Loc.): 0- even, 1- set back, 2- protrudes

Scour cond.: 0- not evident; 1- evident (comment); 2- footing exposed; 3-undermined footing; 4- piling exposed; 5- settled; 6- failed

Materials: 1- Concrete; 2- Stone masonry or drywall; 3- steel or metal; 4- wood

79. Abutment comments (eg. undermined penetration, unusual scour processes, debris, etc.):

$-$

1

The main channel flow is along the left abutment.

80. Wingwalls:

Exist? Material? Scour Scour Exposure $\begin{aligned} & 81 . \\ & \text { Angle? Length? }\end{aligned}$ Condition? depth? depth?

USLWW:

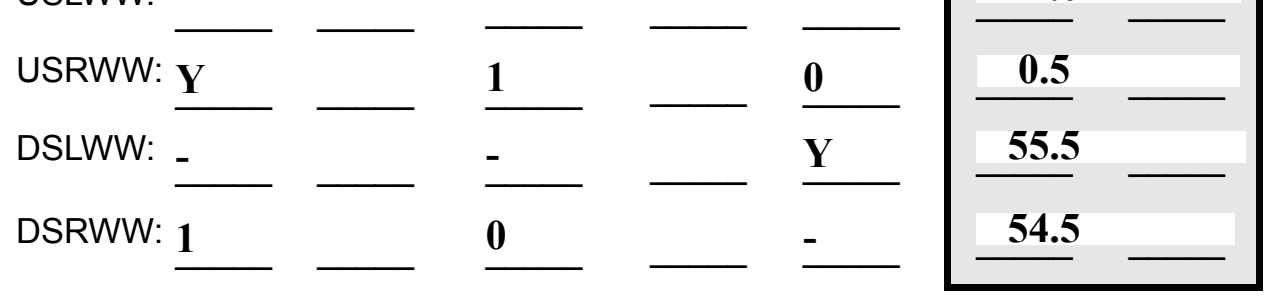

Wingwall materials: 1- Concrete; 2- Stone masonry or drywall; 3- steel or metal; 4- wood

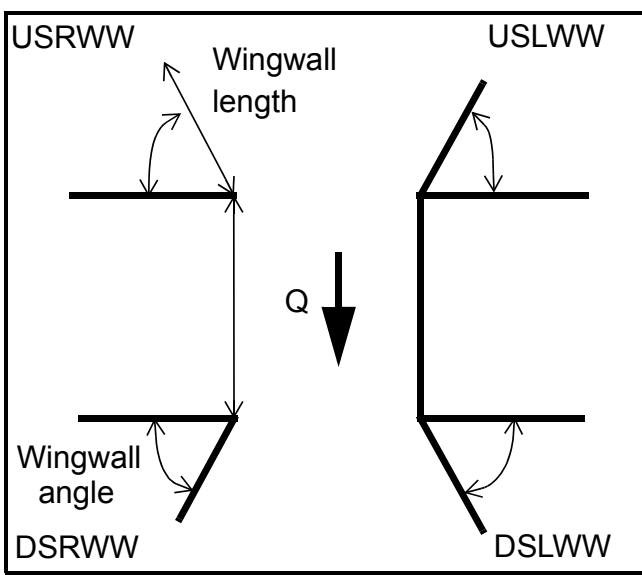

82. Bank / Bridge Protection:

\begin{tabular}{|l|l|l|l|l|l|l|l|l|}
\hline Location & USLWW & USRWW & LABUT & RABUT & LB & RB & DSLWW & DSRWW \\
\hline Type & - & $\mathbf{0}$ & $\mathbf{Y}$ & - & - & - & - & - \\
\hline Condition & $\mathbf{Y}$ & - & $\mathbf{1}$ & - & - & - & - & - \\
\hline Extent & $\mathbf{1}$ & - & $\mathbf{0}$ & $\mathbf{0}$ & $\mathbf{0}$ & $\mathbf{0}$ & $\mathbf{0}$ & - \\
\hline
\end{tabular}

Bank / Bridge protection types: 0- absent; 1- < 12 inches; 2- < 36 inches; 3- < 48 inches; 4- < 60 inches; 
83. Wingwall and protection comments (eg. undermined penetration, unusual scour processes, etc.):

-
-
-
-
-
0
-
-
0
-
-

\section{Piers:}

84. Are there piers? _ _ (Y or if $N$ type ctrl-n pr)

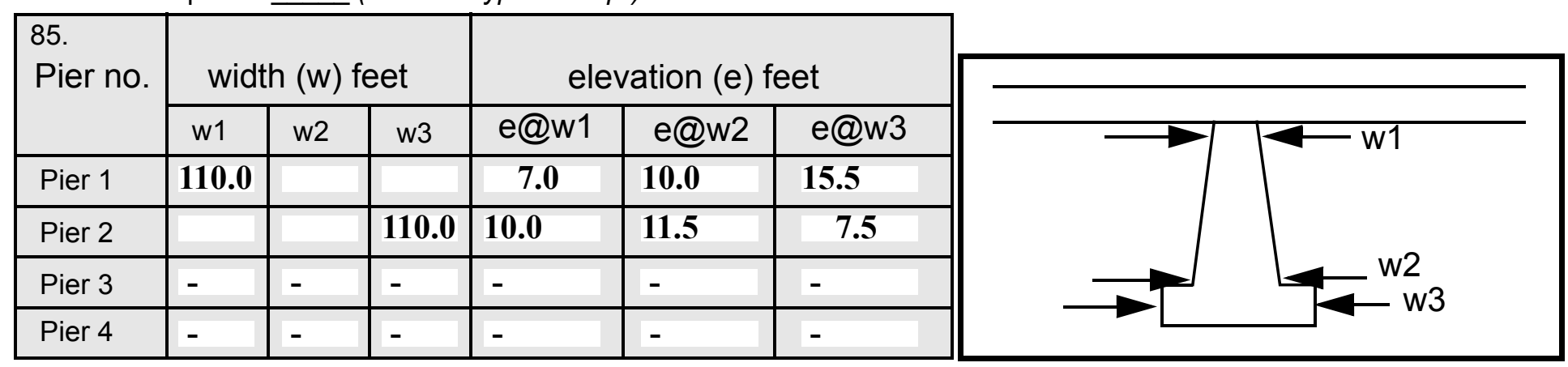

\begin{tabular}{|l|l|l|l|l|}
\hline Level 1 Pier Descr. & 1 & \multicolumn{1}{|c|}{2} & 3 & \multicolumn{1}{|c|}{} \\
\hline 86. Location (BF) & & - & - & - \\
\hline 87. Type & & - & - & - \\
\hline 88. Material & & - & - & - \\
\hline 89. Shape & & - & - & - \\
\hline 90. Inclined? & & - & - & - \\
\hline 91. Attack $\angle$ (BF) & & - & - & - \\
\hline 92. Pushed & & - & - & - \\
\hline 93. Length (feet) & - & - & - & - \\
\hline 94. \# of piles & & - & - & - \\
\hline 95. Cross-members & & - & - & - \\
\hline 96. Scour Condition & & - & - & - \\
\hline 97. Scour depth & $\mathbf{N}$ & - & - & - \\
\hline 98. Exposure depth & - & - & - & - \\
\hline
\end{tabular}

LFP, LTB, LB, MCL, MCM, MCR, RB, RTB, RFP

1- Solid pier, 2- column, 3- bent

1-Wood; 2- concrete; 3- metal; 4- stone

1- Round; 2- Square; 3- Pointed

Y-yes; $N-$ no

$L B$ or $R B$

0- none; 1- laterals; 2- diagonals; 3- both

0- not evident; 1- evident (comment);

2- footing exposed; 3- piling exposed;

4- undermined footing; 5- settled; 6- failed 
99. Pier comments (eg. undermined penetration, protection and protection extent, unusual scour processes, etc.):

-
-
-
-
-
-
-
-
-

100.

\section{E. Downstream Channel Assessment}

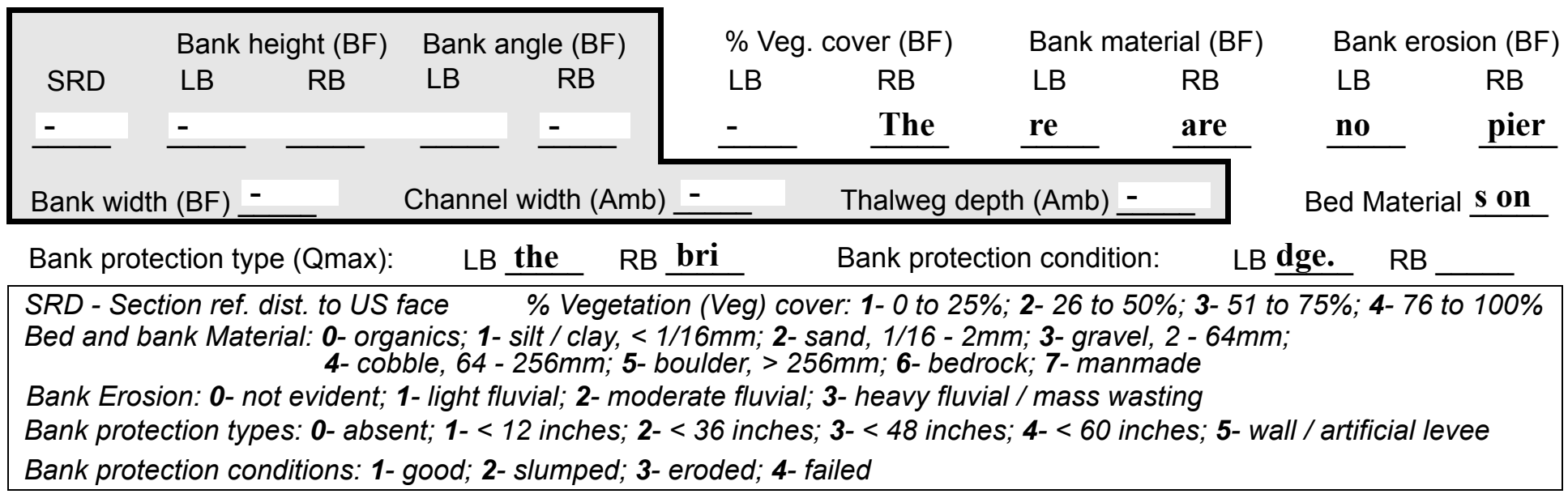

Comments (eg. bank material variation, minor inflows, protection extent, etc.):

101. Is a drop structure present? 1 ( $Y$ or $N$, if $N$ type ctrl-n ds) 102. Distance: _ _ feet 103. Drop: _ _ feet 104. Structure material: 3 (1- steel sheet pile; 2- wood pile; 3- concrete; 4- other) 105. Drop structure comments (eg. downstream scour depth): 1 1

The right bank protection extends from $17 \mathrm{ft}$ DS to $45 \mathrm{ft}$ DS. After $45 \mathrm{ft}$ DS, the right bank is moderately eroded. In this area there are trees leaning into the channel. The right bank protection is slumped into the channel from $6 \mathrm{ft}$ DS to $23 \mathrm{ft}$ DS at the cut-bank. The right bank material includes boulder protection. The left bank protection extends from the end of the wingwall at $26 \mathrm{ft}$ DS to $42 \mathrm{ft}$ DS. The left bank erosion 
106. Point/Side bar present? ext (Y or $N$. if $N$ type ctrl-n pb)Mid-bar distance: ends Mid-bar width: from

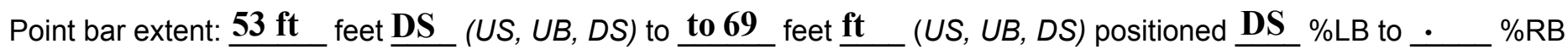
Material:

Point or side bar comments (Circle Point or Side; note additional bars, material variation, status, etc.):

Is a cut-bank present? (Y or if $N$ type ctrl- $n$ cb) Where? (LB or $R B)$

Mid-bank distance:

Cut bank extent: feet (US, UB, DS) to $\underline{\mathbf{N}}$ feet (US, UB, DS)

Bank damage: NO (1- eroded and/or creep; 2- slip failure; 3- block failure)

Cut bank comments (eg. additional cut banks, protection condition, etc.):

DROP STRUCTURE

Is channel scour present? Scour dimensions: Length $\mathbf{Y}$ Width 27 ( $Y$ or if $N$ type ctrl-n cs)

Mid-scour distance:

Scour comments (eg. additional scour areas, local scouring process, etc.):

38

DS

0

45

Are there major confluences? 32 ( $Y$ or if $N$ type ctrl-n $m c$ )

Confluence 1: Distance -

Enters on ( $L B$ or $R B)$

Confluence 2: Distance

Enters on $\underline{\mathbf{Y}}$ (LB or $R B)$
Positioned $\underline{14} \%$ LB to DS $\%$ RB Confluence comments (eg. confluence name):

13

6

\section{F. Geomorphic Channel Assessment}

107. Stage of reach evolution DS

1- Constructed

2- Stable

3- Aggraded

4- Degraded

5- Laterally unstable

6- Vertically and laterally unstable 
108. Evolution comments (Channel evolution not considering bridge effects; See HEC-20, Figure 1 for geomorphic descriptors):

23

DS

2

The bank protection has failed and is slumped into the channel. An additional cut bank is from $45 \mathrm{ft}$ DS to $73 \mathrm{ft}$ DS on the right bank. Mid-bank distance is at $60 \mathrm{ft}$ DS. The bank in this area has been eroded.

$\mathbf{N}$

$-$

$-$ 


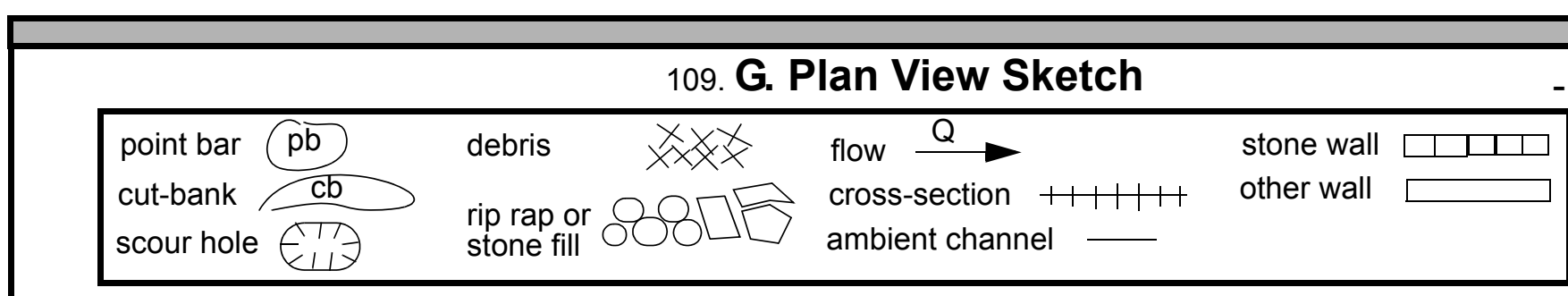


APPENDIX F:

SCOUR COMPUTATIONS 
SCOUR COMPUTATIONS

\begin{tabular}{|c|c|c|c|}
\hline Structure Number: WNDHTH00020010 & & Town: & WINDHAM \\
\hline Road Number: $\quad$ FAS 123 & & County: & WINDHAM \\
\hline Middle Branch Wi & Liams Rive & & \\
\hline Initials LKS & Checked: & $\mathrm{RF}$ & \\
\hline Analysis of contraction scour, liv & -bed or $\mathrm{cl}$ & lear wate & \\
\hline $\begin{array}{l}\text { Critical Velocity of Bed Material } \\
\text { VC=11.21*y } 1^{\wedge} 0.1667 * \mathrm{D} 50^{\wedge} 0.33 \text { with } \mathrm{S}\end{array}$ & $\begin{array}{l}\text { Converted } \\
=2.65\end{array}$ & to Engl & sh units) \\
\hline (Richardson and others, 1995, p. 2 & eq. 16) & & \\
\hline Approach Section & & & \\
\hline Characteristic & $100 \mathrm{yr}$ & $500 \mathrm{yr}$ & other $Q$ \\
\hline Total discharge, cfs & 630 & 920 & 0 \\
\hline Main Channel Area, ft2 & 148 & 191 & 0 \\
\hline Left overbank area, ft2 & 57 & 99 & 0 \\
\hline Right overbank area, ft2 & 0 & 7 & 0 \\
\hline Top width main channel, ft & 28 & 29 & 0 \\
\hline Top width L overbank, ft & 23 & 35 & 0 \\
\hline Top width $\mathrm{R}$ overbank, ft & 0 & 22 & 0 \\
\hline D50 of channel, ft & 0.20135 & 0.20135 & 0 \\
\hline D50 left overbank, ft & -- & -- & -- \\
\hline D50 right overbank, ft & -- & -- & -- \\
\hline y1, average depth, MC, ft & 5.3 & 6.6 & ERR \\
\hline y1, average depth, LOB, ft & 2.5 & 2.8 & ERR \\
\hline Y1, average depth, ROB, ft & ERR & 0.3 & ERR \\
\hline Total conveyance, approach & 13090 & 20645 & 0 \\
\hline Conveyance, main channel & 10345 & 15441 & 0 \\
\hline Conveyance, LOB & 2745 & 5129 & 0 \\
\hline Conveyance, ROB & 0 & 75 & 0 \\
\hline Percent discrepancy, conveyance & 0.0000 & 0.0000 & ERR \\
\hline Qm, discharge, MC, Cfs & 497.9 & 688.1 & ERR \\
\hline Q1, discharge, LOB, cfs & 132.1 & 228.6 & $\mathrm{ERR}$ \\
\hline Qr, discharge, ROB, Cfs & 0.0 & 3.3 & ERR \\
\hline $\mathrm{Vm}$, mean velocity $\mathrm{MC}$, ft/s & 3.4 & 3.6 & $\mathrm{ERR}$ \\
\hline Vl, mean velocity, LOB, ft/s & 2.3 & 2.3 & ERR \\
\hline Vr, mean velocity, ROB, ft/s & ERR & 0.5 & ERR \\
\hline Vc-m, crit. velocity, $\mathrm{MC}, \mathrm{ft} / \mathrm{s}$ & 8.7 & 9.0 & $\mathrm{~N} / \mathrm{A}$ \\
\hline VC-l, crit. velocity, LOB, ft/s & ERR & ERR & ERR \\
\hline VC-r, crit. velocity, ROB, ft/s & ERR & ERR & ERR \\
\hline Results & & & \\
\hline Live-bed(1) or Clear-Water(0) Cont & action Sco & our? & \\
\hline Main Channel & 0 & 0 & $\mathrm{~N} / \mathrm{A}$ \\
\hline Left Overbank & $\mathrm{N} / \mathrm{A}$ & $\mathrm{N} / \mathrm{A}$ & $\mathrm{N} / \mathrm{A}$ \\
\hline Right Overbank & $\mathrm{N} / \mathrm{A}$ & N/A & $\mathrm{N} / \mathrm{A}$ \\
\hline
\end{tabular}


Clear Water Contraction Scour in MAIN CHANNEL

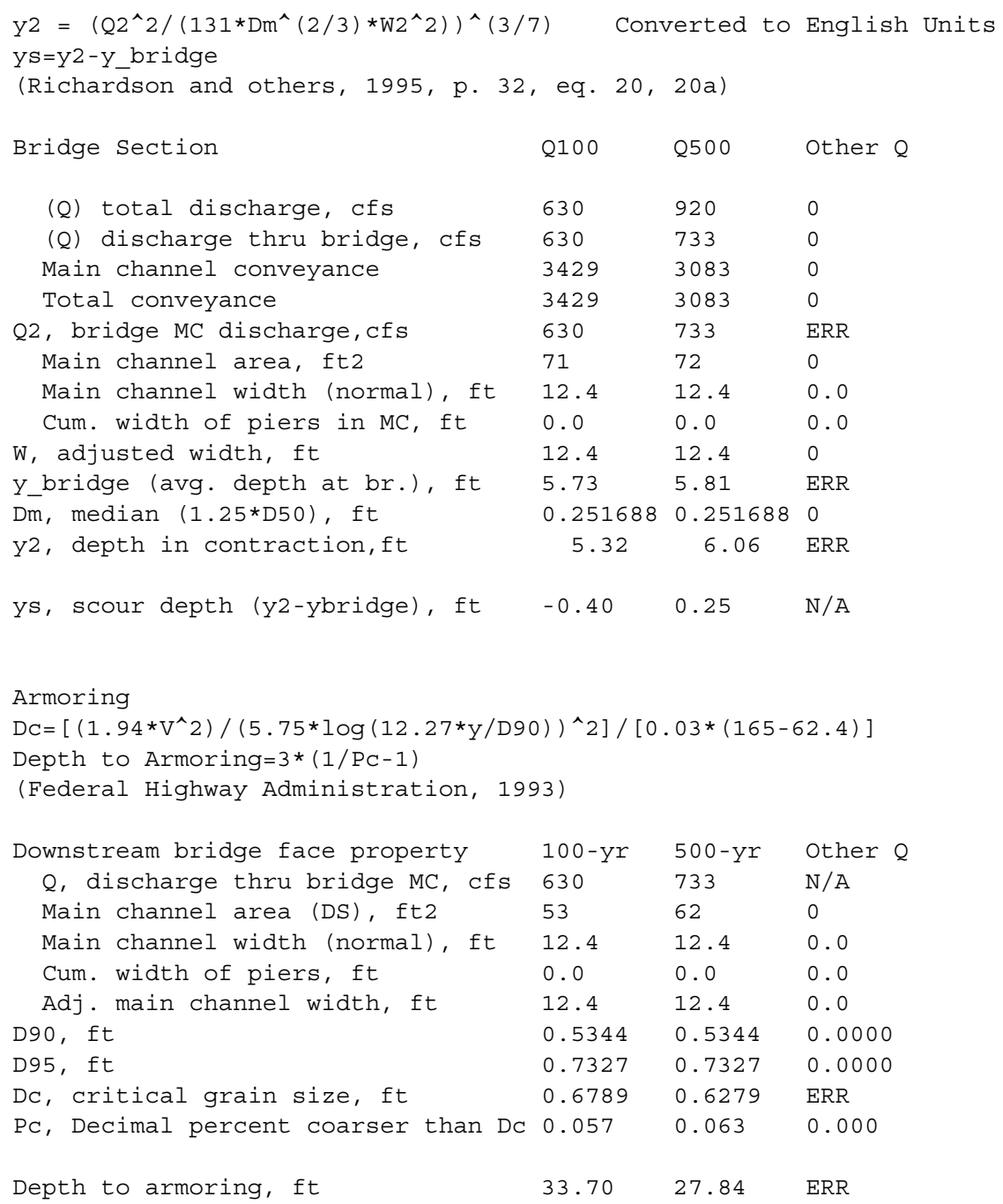


Pressure Flow Scour (contraction scour for orifice flow conditions)

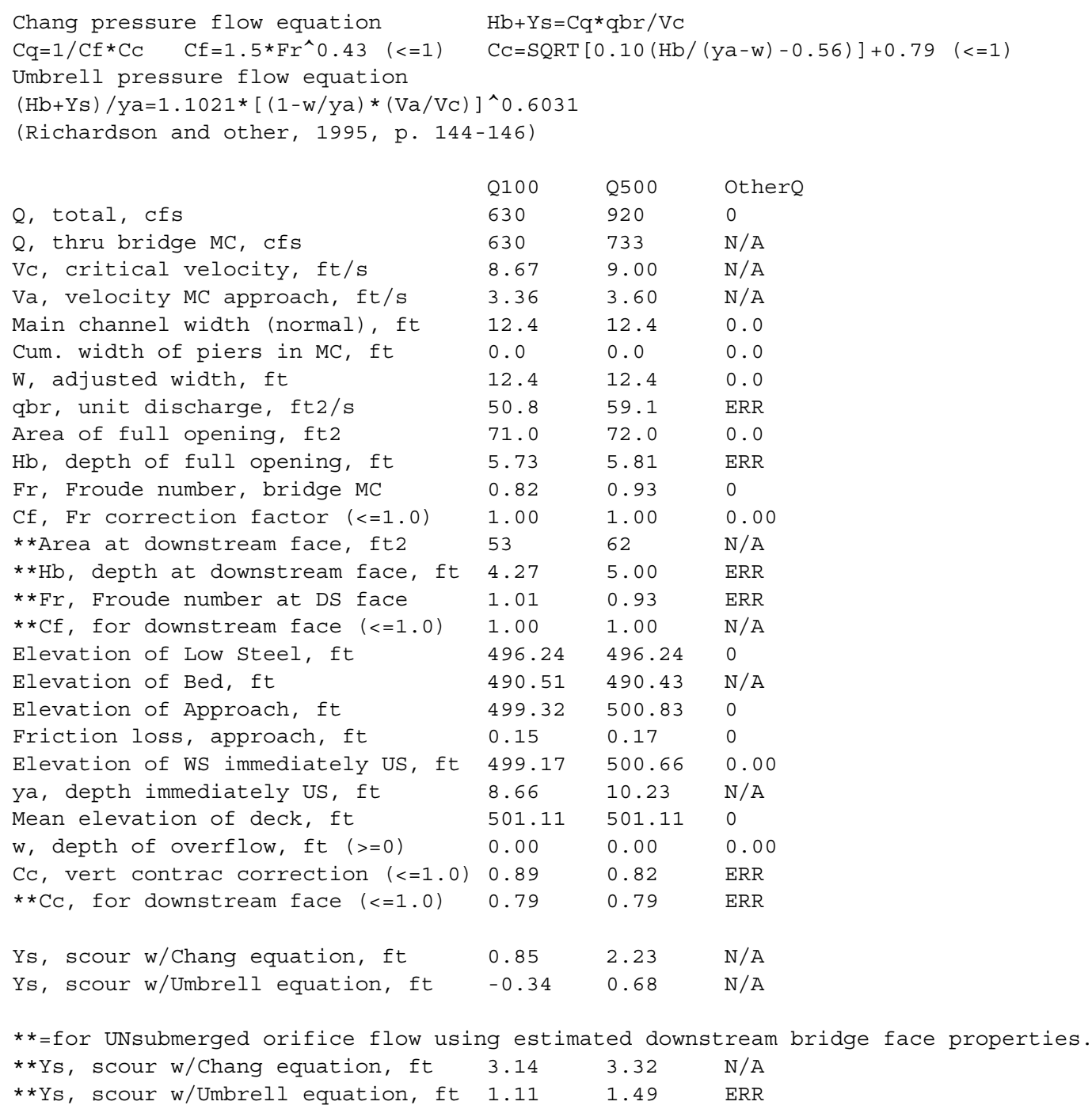

In UNsubmerged orifice flow, an adjusted scour depth using the Laursen equation results and the estimated downstream bridge face properties 


\begin{tabular}{|c|c|c|c|}
\hline y2, from Laursen's equation, ft & 5.32 & 6.06 & 0.00 \\
\hline WSEL at downstream face, ft & 494.49 & 495.46 & -- \\
\hline Depth at downstream face, ft & 4.27 & 5.00 & $\mathrm{~N} / \mathrm{A}$ \\
\hline Ys, depth of scour (Laursen), ft & 1.05 & 1.06 & $\mathrm{~N} / \mathrm{A}$ \\
\hline
\end{tabular}

Abutment scour

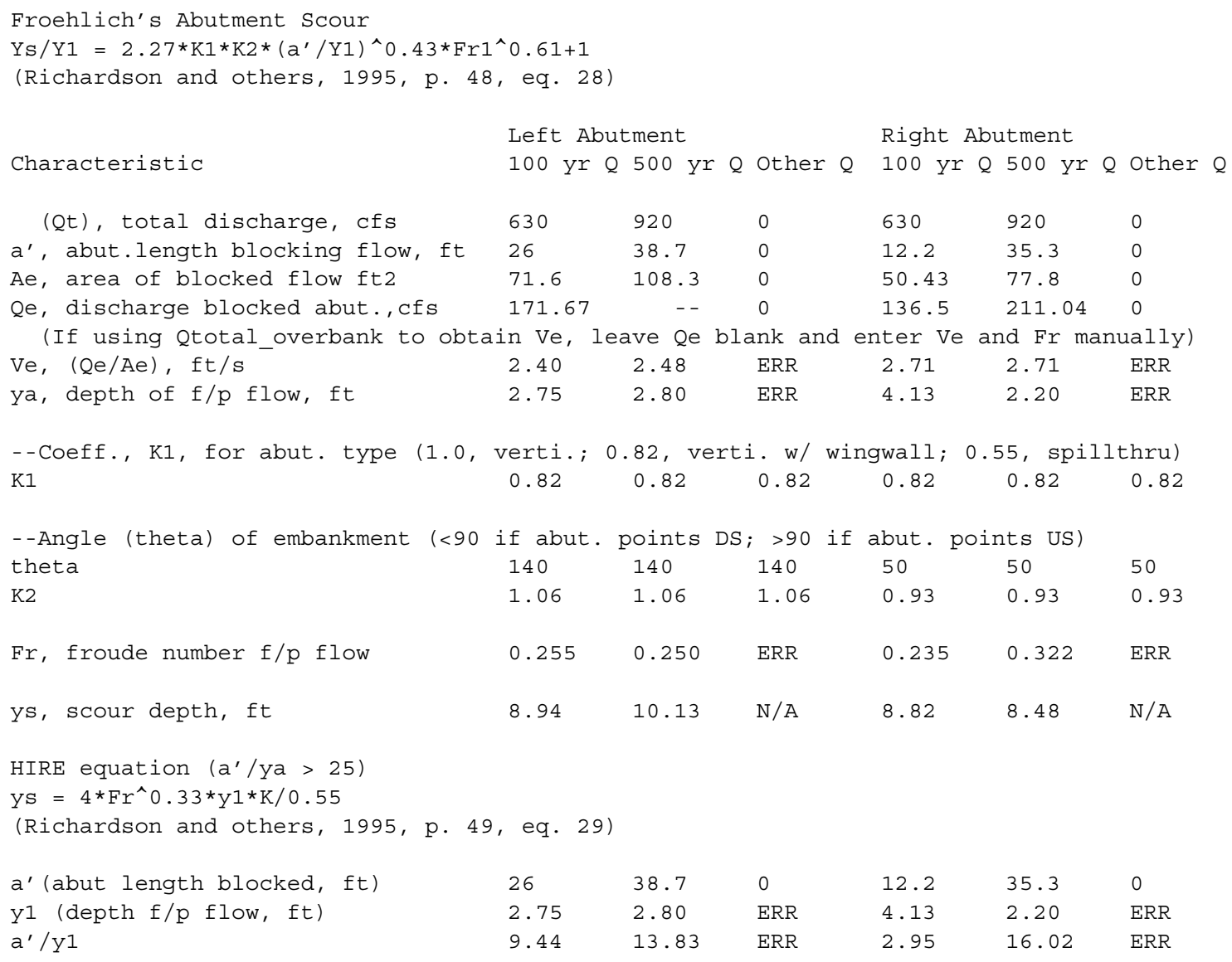

$\begin{array}{llllll}26 & 38.7 & 0 & 12.2 & 35.3 & 0 \\ 2.75 & 2.80 & \text { ERR } & 4.13 & 2.20 & \text { ERR } \\ 9.44 & 13.83 & \text { ERR } & 2.95 & 16.02 & \text { ERR }\end{array}$




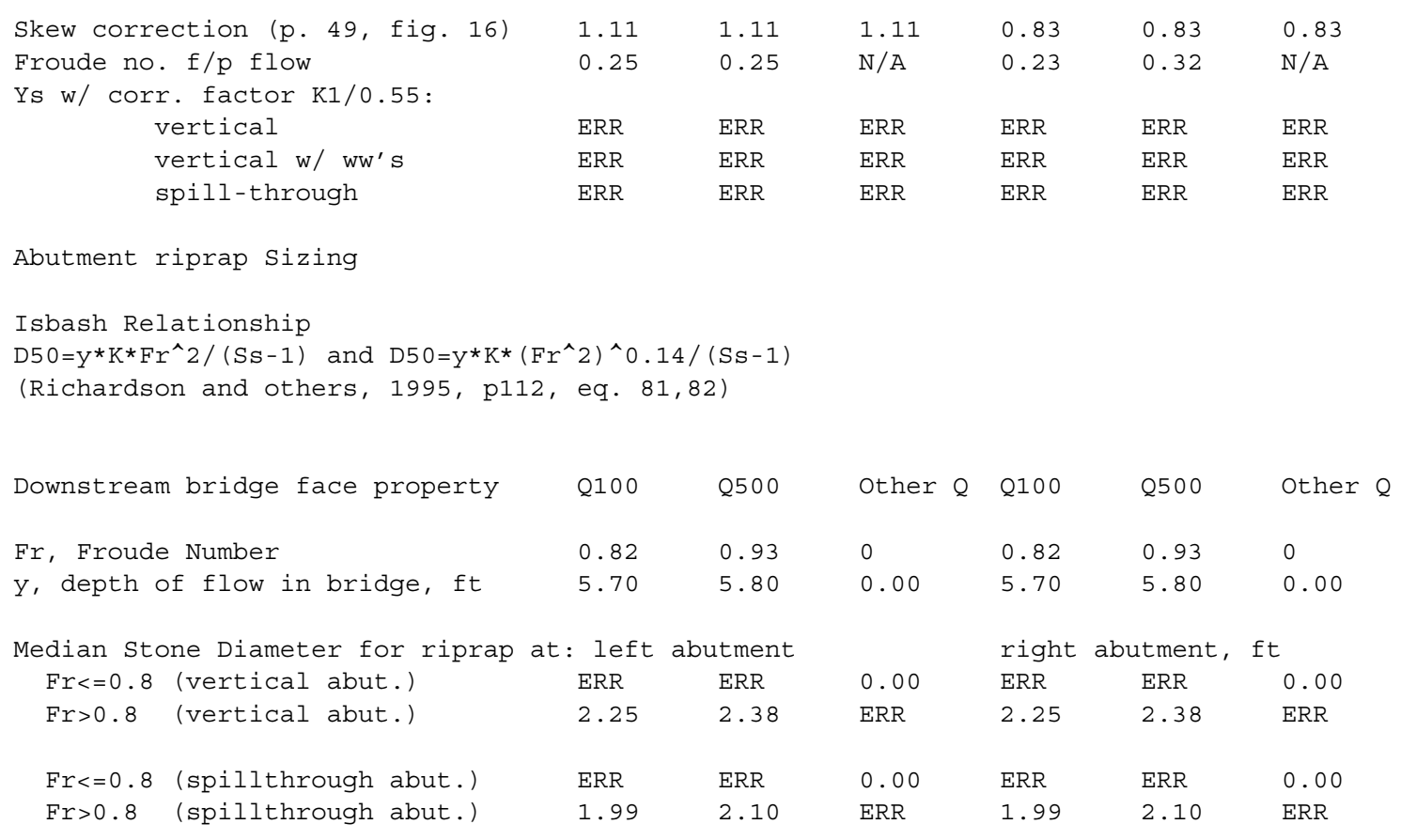

